\title{
Applying a Trojan Horse Strategy to Ruthenium Complexes in the Pursuit of Novel Antibacterial Agents
}

\author{
Quentin Laurent, Lucinda K. Batchelor, and Paul J. Dyson*(i)
}

Institut des Sciences et Ingénierie Chimiques, École Polytechnique Fédérale de Lausanne (EPFL), CH-1015 Lausanne, Switzerland

Supporting Information

ABSTRACT: Siderophores are iron chelators secreted by bacteria to scavenge iron(III) from their surrounding environment. They possess their own internalization pathway that is sufficiently unselective to be hijacked, making them suitable for Trojan Horse strategy applications. A commercially available siderophore, deferoxamine B (DFO), was derivatized at the primary amine with carboxylic acids bearing different ligands to afford mono- and bidentate complexes with ruthenium as well as a RAPTA-like complex in which DFO is tethered to the coordinated arene ring. These compounds were tested for antibacterial activity against key ESKAPE pathogens, and antiproliferative studies against healthy (HEK-293) and tumoral (A2780) human cells were performed. Some of the complexes displayed interesting dual anticancer and antibacterial properties. Combining these two properties within a single compound is desirable as patients treated for cancer have a weakened ability for fighting infections.

\section{INTRODUCTION}

Since the discovery of penicillin in $1928,{ }^{1}$ a tremendous number of antimicrobial drugs have been developed targeting bacteria (antibacterial), fungi (antifungal), viruses (antiviral), and parasites (antiparasitic). As a consequence, many common yet fatal illnesses such as pneumonia and tuberculosis have become less deadly. Infections were, for a time, no longer an ever present risk and the dangers linked to surgery or childbirth were drastically reduced. However, due to the intensive worldwide use of antibiotics, especially in agriculture, bacteria and other pathogens have evolved to overcome the effect of these drugs. Antimicrobial resistance (AMR) is becoming increasingly problematic as the discovery of new antibiotic formats has slowed, and is now an issue of global importance. $^{2-5}$ With infections and infectious diseases remaining one of the major causes of death worldwide, ${ }^{6}$ and the emergence of antibacterial resistance, the development of novel classes of antibacterial drugs is of the utmost importance.

Ruthenium(III) and ruthenium(II) drugs are prominent families of anticancer agents, developed in the quest to overcome platinum-based resistance. ${ }^{7}$ At the forefront are NAMI-A, ${ }^{8}$ KP1019, ${ }^{9}$ and NKP-1339, ${ }^{10}$ showing promising results in preclinical and phase $\mathrm{I}$ and I/II clinical trials. Ruthenium(II)-arene complexes such as RAPTA ([Ru $\left(\eta^{6}\right.$ arene $\left.) \mathrm{X}_{2}(\mathrm{PTA})\right]$, PTA $=1,3,5$-triaza-7-phosphaadamantane $)^{11}$ or $\operatorname{RAED}\left(\left(\left[\mathrm{Ru}\left(\eta^{6} \text {-arene }\right)(\mathrm{en}) \mathrm{Cl}\right]^{+} \text {, en }=\text { ethylenediamine }\right)^{12}\right.$ show a wide range of promising anticancer properties. ${ }^{13-15}$ Interestingly, RAPTA-C, arene $=p$-cymene, has also been investigated as a potential antimicrobial agent and displayed activity against different strains of bacteria. ${ }^{16}$ Ruthenium(II)arene complexes represent an interesting platform that can be easily structurally modified, and several clinical drugs such as kinase inhibitor staurosporine, ${ }^{17}$ glutathione-S-transferase inhibitor ethacrynic acid, ${ }^{18}$ antifungal agents, ${ }^{19}$ or antibacterial quinolones ${ }^{20,21}$ have been coupled to them, either to augment their anticancer activity or to have dual-functioning drug candidates, being both antibacterial and anticancer agents. ${ }^{20,21}$ Coupling these two therapeutic effects is desirable in the clinics where patients treated for cancer often show weakened ability to fight infections. ${ }^{22}$

Iron is an essential element for almost all organisms (animals, plants, and micro-organisms), being involved in electron transport and metabolic processes from photosynthesis to DNA biosynthesis. ${ }^{23}$ This involvement in so many biological reactions makes it a vital element for the survival of living organisms. While animals can source iron from food, plants and microorganisms need to obtain it from their surrounding environment. The most common strategy is the use of ferric ion chelators as solubilizing agents. ${ }^{24}$ This is achieved through the secretion of siderophores (literally "iron carriers"). These low molecular weight compounds $(<1000 \mathrm{Da})$ possess an extremely high affinity for the $\mathrm{Fe}^{3+}$ ion. ${ }^{25}$ Siderophores are secreted by bacteria in response to an iron restriction to scavenge any $\mathrm{Fe}^{3+}$ that can be found in the surrounding environment. Siderophores usually form hexadentate octahe-

Received: December 13, 2017

Published: February 15, 2018 


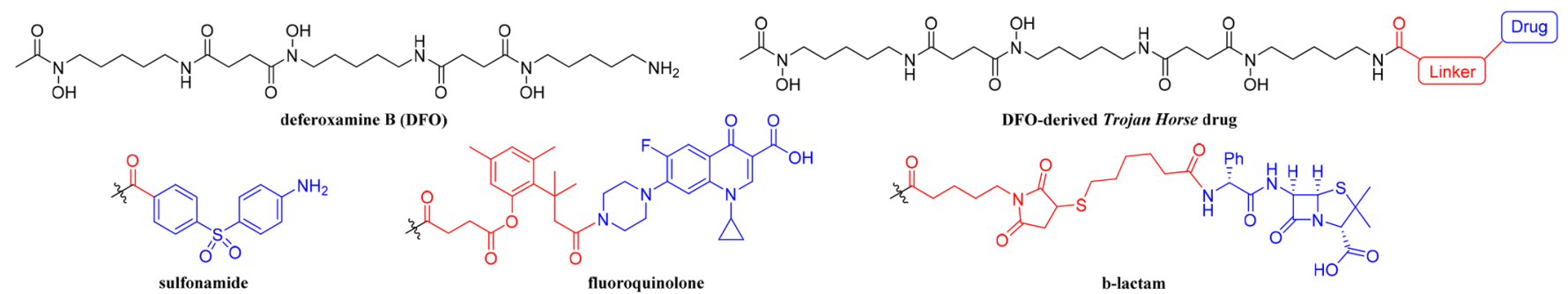

Figure 1. General structure and selected examples of deferoxamine B (DFO) derived Trojan Horse antibacterial drugs.

Scheme 1. Synthesis of Ligands $2 a-c$, and Ruthenium(II) Arene Complexes 3a-c

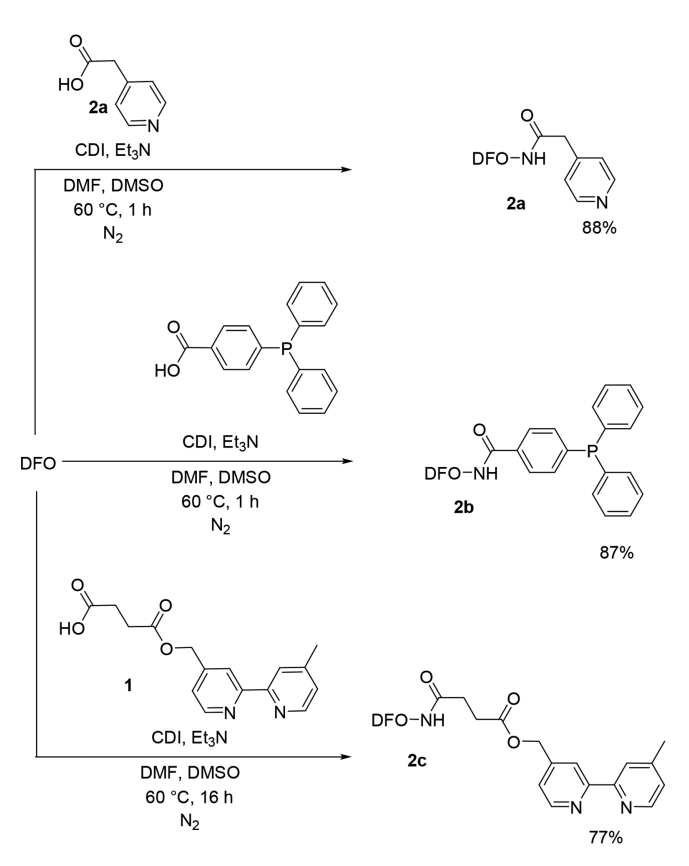

dral complexes with the ferric ion, coordinating through oxygen atoms of hydroxamates, catecholates, a-hydroxycarboxylates or their combination. ${ }^{26}$ Despite being selective for ferrisiderophores, this transport system is unselective enough to induce internalization of exogenous siderophores produced by other bacteria, referred to as xeno-siderophores. ${ }^{27,28}$ Siderophores are vital for bacteria pathogenicity, not only through iron(III) binding. $^{29}$

Reversing the idea of using antibacterial drugs in tumor cells, a Trojan Horse strategy ${ }^{30-35}$ can be applied to deliver anticancer compounds such as ruthenium(II)-arene complexes inside bacteria. Such a strategy takes advantage of the ironuptake mechanism of both Gram-positive and Gram-negative bacteria $^{36}$ to deliver antibiotic moieties directly to the cytoplasm to circumvent membrane-mediated AMR. ${ }^{37}$ The Trojan Horse strategy takes inspiration from the naturally occurring sideromycins, ${ }^{38}$ antibiotics that are covalently linked to siderophores. Based on the study of these sideromycins and their potential, the rational design of synthetic siderophoredrug conjugates was developed, taking advantage of the ability of bacteria to internalize siderophore derivatives. ${ }^{30,32,39-41}$

Used in iron-chelation therapy to treat iron overload, ${ }^{42}$ deferoxamine B (DFO, brand name Desferal) is the only commercially available clinically approved siderophore that is available on a gram scale, making it an interesting candidate for Trojan Horse applications. Several nonferric complexes of this siderophore have been reported. $\mathrm{Al},{ }^{43} \mathrm{Cr},{ }^{44}$ and radioactive
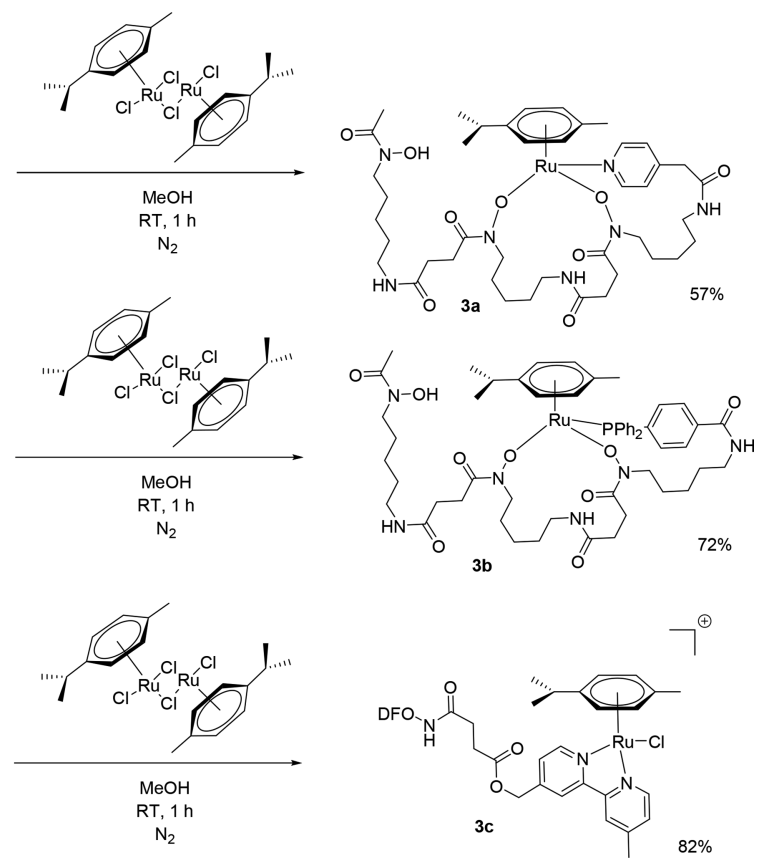

$\left.\left[{ }^{55} \mathrm{Fe}\right]\right]^{45}$ derivatives were studied to investigate the coordination chemistry of this siderophore and the mechanism of ferrisiderophore uptake. DFO and other iron chelators have also been investigated as antimalarial agents acting by iron sequestration. ${ }^{46-48}$ Therapeutically relevant studies have been performed on a gallium-DFO complex, which showed potent antibacterial properties against antibiotic-resistant $P$. aerugino$s a{ }^{49}$ The primary amine of DFO does not participate in the binding to iron and can therefore be functionalized without drastically interfering with the binding. Several synthetic conjugates of DFO and its analogs with antibiotic moieties have also been synthesized and showed antibacterial activity (Figure 1), although usually lower than the drug alone. ${ }^{33,50,51}$ Derivatives of DFO with fluorophores have also been synthesized to study the mechanism of action of such Trojan Horse drugs. ${ }^{52}$ Nonantibacterial drugs, such as DNA intercalators, have also been investigated. ${ }^{33}$ It was found that such compounds degrade DNA through redox damage due to the iron.

Metal-based drugs such as RAPTA complexes have not previously been used as components of Trojan Horse antimicrobial drugs, despite the fact that they display some intrinsic antibacterial properties. Here, we describe the synthesis of conjugates of DFO with ruthenium(II)-arene fragments for potential dual antibacterial/anticancer drugs, and their cytotoxicity studies against human cancerous and healthy cells, as well as resistant and nonresistant bacteria strains. 


\section{RESULTS AND DISCUSSION}

A series of ruthenium(II)-arene complexes modified with DFO, $3 \mathbf{a}-\mathbf{c}$, were prepared using the route presented in Scheme 1. Coupling of carboxylic acids with the primary amine of DFO was optimized from the adaption of a literature procedure. $^{54} \mathrm{~A}$ solution of carboxylic acid activated by carbonyldiimidazole (CDI) at $60{ }^{\circ} \mathrm{C}$ in dimethylformamide (DMF) was added dropwise to a solution of DFO and triethylamine in dimethylsufloxide (DMSO), and the reaction mixture was stirred at $60{ }^{\circ} \mathrm{C}$ and monitored by mass spectrometry (MS). Completion was reached in less than an hour for all ligands $\mathbf{2 a - c}$ (Scheme 1). After purification, they were all obtained in good yields $(77-88 \%)$.

The ruthenium(II) complexes $3 a-c$ were prepared in a single step from $2 \mathbf{a}-\mathbf{c}$ by reaction with the dichloro( $p$ cymene)ruthenium dimer in dry methanol under inert conditions over $1 \mathrm{~h}$. The RAPTA-type complex $3 \mathrm{~d}$ was prepared following a related reported procedure ${ }^{55}$ using TBTU (2-(1H-benzotriazole-1-yl)-1,1,3,3-tetramethylaminium tetrafluoroborate) as the coupling agent in the presence of diisopropylethylamine (DIPEA) in DMSO. Following purification, complexes $3 \mathbf{a}-\mathbf{d}$ were obtained in moderate to good yields $(57-82 \%)$.

All compounds were characterized by ${ }^{1} \mathrm{H},{ }^{13} \mathrm{C}\left\{{ }^{1} \mathrm{H}\right\}$, and where applicable, ${ }^{31} \mathrm{P}$ NMR spectroscopy, ESI-MS, and elemental analysis. NMR spectra of $\mathbf{3 a}$ and $\mathbf{3 b}$ indicate the presence of several species, most notably for $\mathbf{3 b}$ (see Figures S11 and S12), the two chlorides initially bound to ruthenium being substituted by two oxygen atoms of DFO. Several different modes of coordination of DFO to the ruthenium center (through two of its three hydroxyl groups and one hydroxamate) are possible, hence the presence of several species. Although the use of protection groups such as an oxalate moiety could avoid this displacement, ${ }^{55}$ it was found to be unnecessary since, upon addition of an equimolar solution of iron(III) chloride, both $\mathbf{3 a}$ and $\mathbf{3 b}$ mixtures gave only one compound with two chlorides bound to the ruthenium(II) center.

Complex 3a was obtained as one major product and several minor species. Complexation was assessed by positive ion ESIMS and NMR spectroscopy. The aromatic protons of the pyridyl moiety shift from 8.61 (ortho to the nitrogen) and 7.53 (meta to the nitrogen) to 8.47 and $7.26 \mathrm{ppm}$, respectively $\left(\Delta \delta_{\mathrm{H}}\right.$ $\approx 0.2$ and $0.3 \mathrm{ppm})$. The singlet corresponding to the methylene group between the pyridyl and the amide also shifts to lower frequencies $\left(\Delta \delta_{\mathrm{H}} \approx 0.4 \mathrm{ppm}\right)$ and becomes a doublet, indicating the presence of several species. The ${ }^{13} \mathrm{C}\left\{{ }^{1} \mathrm{H}\right\}$ NMR spectrum shows modest changes following complexation to the ruthenium ion, the pyridyl carbons shifting to lower ppm $\left(\Delta \delta_{\mathrm{C}}\right.$ $\approx 0.8 \mathrm{ppm}$ ). Upon addition of $\mathrm{FeCl}_{3}$, the ferrisiderophore ligand was found to rapidly detach from the ruthenium(II) center.

Similar changes were observed for $\mathbf{3 b}$, where the aromatic protons shift to higher frequencies $\left(\Delta \delta_{\mathrm{H}} \approx 0.2 \mathrm{ppm}\right)$ and several peaks from the DFO become split. Complexation was assessed by ${ }^{31} \mathrm{P}$ NMR spectroscopy, where the presence of several species is shown by several peaks that shifted from $-6.94 \mathrm{ppm}$ (ligand $\mathbf{2 b}$ ) to $24.0-26.0 \mathrm{ppm}$, corresponding to the dichloro form and different oxygen-coordinated species at higher frequencies. Upon addition of an equimolar solution of iron(III) chloride, only one peak in the ${ }^{31} \mathrm{P}$ NMR spectrum is observed at $24.9 \mathrm{ppm}$, corresponding to the dichloro species, which is also the only product observed by ESI-MS. Coordination of the ligand to the metal ion is also denoted by peaks in the ${ }^{13} \mathrm{C}\left\{{ }^{1} \mathrm{H}\right\}$ NMR spectrum corresponding to the quaternary carbon atoms covalently linked to the phosphorus, which shift to lower frequencies $\left(\Delta \delta_{\mathrm{C}} \approx 1.5 \mathrm{ppm}\right)$ and larger coupling constants $\left(\Delta^{1} J \approx 17\right.$ and $\left.26 \mathrm{~Hz}\right)$, similar to values found in literature, ${ }^{56}$ although the spectrum is complicated by the presence of several similar species. The amide linking DFO to the triphenylphosphine moiety also shifts to higher frequencies $\left(\Delta \delta_{\mathrm{C}}=4.9 \mathrm{ppm}\right)$.

In contrast to the $\mathbf{2 a}, \mathbf{b} / \mathbf{3} \mathbf{a}, \mathbf{b}$ pairs, the aromatic protons of ligand $2 \mathrm{c}$ all shift to lower field when coordinated to the ruthenium(II) center. The two doublets corresponding to the aromatics protons in the ortho position to the nitrogen atoms shift from 8.65 and 8.54 to 9.48 and $9.38 \mathrm{ppm}$, respectively $\left(\Delta \delta_{\mathrm{H}} \approx 0.8 \mathrm{ppm}\right)$, and their coupling constants increased from 4.9 and 4.8 to 5.7 and $6.0 \mathrm{~Hz}$. The two aromatic singlets shift from 8.34 and 8.24 to 8.64 and $8.51 \mathrm{ppm}\left(\Delta \delta_{\mathrm{H}} \approx 0.3 \mathrm{ppm}\right)$, and the two remaining doublets shift from 7.40 and 7.30 to 7.72 and $7.65 \mathrm{ppm}\left(\Delta \delta_{\mathrm{H}} \approx 0.3 \mathrm{ppm}\right)$. These last two sets are less affected than the protons directly ortho to the nitrogen as they are further from the ruthenium center. Even more remote is the methylene group between the pyridyl moiety and the ester, which only shifts by $0.2 \mathrm{ppm}$ (5.22 to $5.40 \mathrm{ppm}$ ). Related changes are also observed in the ${ }^{13} \mathrm{C}\left\{{ }^{1} \mathrm{H}\right\}$ NMR spectrum after coordination with the aromatic carbon atoms shifting to higher frequencies $\left(\Delta \delta_{\mathrm{C}} \approx 0.3\right.$ to $\left.3.9 \mathrm{ppm}\right)$.

As the environment of the ruthenium center in $\mathbf{3 d}$ is close to that of its starting material (Scheme 2), coupling with DFO to

Scheme 2. Synthesis of RAPTA Complex Derivative 3d
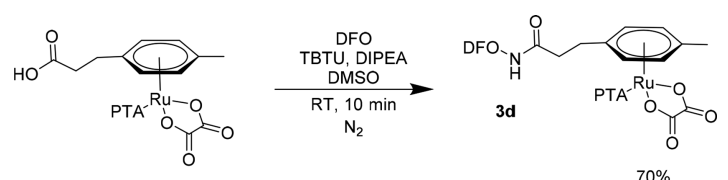

afford 3d does not induce drastic changes in the NMR spectra, except for the addition of new peaks derived from the DFO moiety. The ${ }^{1} \mathrm{H}$ NMR spectrum presents peaks for both the DFO moiety and the RAPTA complex with very minor changes, and the peak in the ${ }^{31} \mathrm{P}$ NMR spectrum corresponding to the PTA moiety only shifts from -32.2 to $-33.3 \mathrm{ppm}$.

The cytotoxicity of DFO, ligands $2 \mathbf{a}-\mathbf{c}$, and ruthenium(II) complexes $3 \mathbf{a}-\mathbf{d}$ in the absence or presence of iron(III) was assessed using the 3-(4,5-dimethyl-2-thiazolyl)-2,5-diphenyl$2 \mathrm{H}$-tetrazolium bromide (MTT) assay ${ }^{57}$ against human ovarian carcinoma cell lines (A2780) and human embryonic kidney (HEK-293) cells (Table 1). The ferrisiderophore species were obtained by mixing equimolar DMSO solutions of the corresponding siderophore derivative with $\mathrm{FeCl}_{3}$. Comparison between this method and the separate synthesis and purification of the ferrisiderophore compounds was performed and shown to yield similar results. The cytotoxicities of cisplatin and RAPTA-C were evaluated as positive and negative controls, respectively. All compounds were predissolved in DMSO before being immediately diluted into the appropriate cell culture medium. Stability studies under pseudocell culture conditions of $100 \mathrm{mM} \mathrm{NaCl}$ in $\mathrm{H}_{2} \mathrm{O}$ and 5\% DMSO were conducted on $3 \mathrm{a}-\mathbf{d}$ over $72 \mathrm{~h}$. The stability was monitored via ESI-MS or ${ }^{1} \mathrm{H}$ and ${ }^{31} \mathrm{P}$ NMR spectroscopy. All complexes showed good stability under these conditions except for $\mathbf{3 b}$ in absence of iron(III), where the arene ligand was displaced (see 
Table 1. In Vitro Antiproliferative Activity of Compounds DFO, $2 a-c$, and $3 a-d$ in the Absence/Presence of 1 equiv of Iron(III) and Cisplatin and RAPTA-C against Human Ovarian Carcinoma (A2780) and Human Embryonic Kidney 293 (HEK-293) Cell Lines after 72 h Exposure ${ }^{a}$

\begin{tabular}{lccccc} 
& \multicolumn{2}{c}{ A2780 } & & \multicolumn{2}{c}{ HEK-293 } \\
\cline { 2 - 3 } \cline { 5 - 6 } compd & no Fe & Fe & & no Fe & Fe \\
DFO & $13 \pm 6$ & $>200$ & & $4 \pm 2$ & $>200$ \\
2a & $>200$ & $>200$ & & $>200$ & $>200$ \\
$2 b$ & $21 \pm 1$ & $>200$ & & $143 \pm 23$ & $>200$ \\
2c & $20 \pm 2$ & $>200$ & & $19 \pm 2$ & $58 \pm 4$ \\
3a & $>200$ & n.a. & & $>200$ & n.a. \\
3b & $109 \pm 6$ & $33 \pm 2$ & & $>200$ & $>200$ \\
3c & $48 \pm 4$ & $91 \pm 10$ & & $23 \pm 1$ & $>200$ \\
3d & $107 \pm 2$ & $>200$ & & $15 \pm 2$ & $>200$ \\
cisplatin & \multicolumn{2}{c}{$1.5 \pm 0.3$} & & $7.3 \pm 0.6$ \\
RAPTA-C & \multicolumn{2}{c}{$>200$} & & \multicolumn{2}{c}{$>200$}
\end{tabular}

${ }^{a}$ Values are given as the mean \pm standard deviation $(\mu \mathrm{M})$.

Figure S2). Notably, the ferrisiderophore analogue of $\mathbf{3 b}$ is stable under these conditions.

Interestingly, introduction of iron(III) reduces the cytotoxicity of the compounds, presumably as the three hydroxyl groups of the siderophore are no longer free. This observation is apparent for DFO where, upon addition of iron(III), the cytotoxicity changes from the micromolar range ( $13 \pm 6$ and 4 $\pm 2 \mu \mathrm{M}$ against A2780 and HEK-293, respectively) to inactive at the maximum dose tested. For potential therapeutic applications, the ferrisiderophore form would not only help to avoid unwanted toxicity, but ferrisiderophores are preferentially internalized in bacteria so this form facilitates targeting. In presence of iron(III), ligand $2 c$ is the only ligand with an antiproliferative effect against the nontumorigenic HEK-293 cells.

Complexes $\mathbf{3 b}, \mathbf{c}$ possess moderate cytotoxicity against the A2780 cell line. In presence of iron(III), 3b displays higher cytotoxicity against A2780 cells, contrary to the other compounds $(33 \pm 2 \mu \mathrm{M}$ against $109 \pm 6 \mu \mathrm{M}$ in absence of iron(III)). This may be explained by the decoordination of DFO from the ruthenium ion, as its affinity for iron(III) is higher. A 7-fold selectivity toward A2780 cells is observed for $3 \mathbf{b}$ in the presence of iron(III), with IC $_{50}$ values of $33 \pm 2$ and $>200 \mu \mathrm{M}$, which is higher than the 5-fold selectivity of cisplatin although the overall activity is lower. Despite being cytotoxic to healthy HEK-293 cells in its iron(III)-free form $\left(\mathrm{IC}_{50}=23 \pm 1\right.$ $\mu \mathrm{M})$, complex $3 \mathrm{c}$ is also selective for A2780 cell line in the presence of iron(III) $(91 \pm 10 \mu \mathrm{M}$ versus $>200 \mu \mathrm{M})$, although with a lower selectivity than $3 \mathrm{~b}$. Due to the structural similarity with $\mathbf{3 b}$, complex $\mathbf{3 a}$ might be expected to follow the same trend, but the pyridyl ligand $2 \mathrm{a}$ was found to dissociate from the ruthenium center upon addition of iron(III). 3a shows no cytotoxicity against $\mathrm{A} 2780$ and HEK cells $\left(\mathrm{IC}_{50}>200 \mu \mathrm{M}\right)$. Complex $3 \mathbf{d}$ is cytotoxic to both cell lines in its iron(III)-free form ( $107 \pm 2$ and $15 \pm 2 \mu \mathrm{M}$ against A2780 and HEK-293 cell lines, respectively) but inactive when iron(III) was added.

Contrary to previously described RAPTA complexes such as RAPTA-C, which possess low cytotoxicities with $\mathrm{IC}_{50}$ values $>200 \mu \mathrm{M},{ }^{11}$ complexes $3 \mathrm{a}-\mathrm{d}$ are moderately cytotoxic against human cell lines. As they are structurally similar, cytotoxicity arises from the functionalization with DFO. Note that other RAPTA-type compounds modified with functional bioactive molecules at the coordinated arene ring are often cytotoxic. ${ }^{40,58-60}$ The activity of both $3 \mathbf{b}$ and $3 \mathbf{c}$ is in the micromolar range, with $\mathrm{IC}_{50}$ values 20 to 60 times higher than cisplatin, albeit comparable to other ruthenium(II) complexes bearing organic bioactive moieties ${ }^{61,62}$ or CAP ligands instead of the PTA moiety, ${ }^{63}$ but with much higher selectivity toward cancerous cell lines. The cancer cell selectivity observed for $\mathbf{3 b}$ is higher than cisplatin and similar to ruthenium(II)-arene compounds bearing perfluorinated alkyl chains ${ }^{64}$ that show promising in vivo antitumor effects. ${ }^{65}$

All compounds were tested for activity against four of the key ESKAPE pathogens (S. aureus, K. pneumoniae, A. baumannii, and $P$. aeruginosa) ${ }^{66}$ as well as E. coli and two fungi, C. albicans and $C$. neoformans. Inhibition of bacterial growth at a single concentration of $20 \mu \mathrm{M}$ after $18 \mathrm{~h}$ of incubation was determined for $\mathbf{2} \mathbf{a}-\mathbf{c}$ and $\mathbf{3} \mathbf{a}-\mathbf{d}$ (Table 2), as well as for some other ruthenium(II) arene complexes (Table S1). DFO itself and ligands $\mathbf{2 a}-\mathbf{c}$ were found to be inactive, some even promoting bacterial growth, presumably as they help to deliver iron(III) to the organism. These data show which bacterial strains and fungi were more susceptible to internalize DFO, as they grow better in the presence of the siderophore, i.e. E. coli, $P$. aeruginosa, and C. neoformans. S. aureus growth was slightly inhibited by ligands $2 \mathbf{a}-\mathbf{c}$, possibly via iron(III) sequestration. $K$. pneumoniae, A. baumannii, and C. albicans growth showed no significant change when incubated with the compounds. The lack of toxicity of the ligand implies that any further activity found for ruthenium complexes $3 \mathbf{a}-\mathbf{d}$ emanates from the ruthenium fragment.

Surprisingly, the same trend was observed for complexes $\mathbf{3 b}-$ d, which all promoted the growth of $E$. coli and P. aeruginosa in the presence of iron(III), whereas modest growth inhibition

Table 2. Growth Inhibition of Different Bacterial Strains and Fungi at $20 \mu \mathrm{M}$ of DFO, 2a-c, and $3 a-d$ in the Absence or Presence of 1 equiv of Iron(III) after 18 h Incubation $^{a}$

\begin{tabular}{|c|c|c|c|c|c|c|c|c|c|c|c|c|c|c|}
\hline \multirow[b]{2}{*}{ compd } & \multicolumn{2}{|c|}{ S. aureus } & \multicolumn{2}{|c|}{ E. coli } & \multicolumn{2}{|c|}{ K. pneumonia } & \multicolumn{2}{|c|}{ P. aeruginosa } & \multicolumn{2}{|c|}{ A. baumannii } & \multicolumn{2}{|c|}{ C. albicans } & \multicolumn{2}{|c|}{ C. neoformans } \\
\hline & no $\mathrm{Fe}$ & $\mathrm{Fe}$ & no $\mathrm{Fe}$ & $\mathrm{Fe}$ & no $\mathrm{Fe}$ & $\mathrm{Fe}$ & no $\mathrm{Fe}$ & $\mathrm{Fe}$ & no $\mathrm{Fe}$ & $\mathrm{Fe}$ & no $\mathrm{Fe}$ & $\mathrm{Fe}$ & no $\mathrm{Fe}$ & $\mathrm{Fe}$ \\
\hline DFO & 23 & 25 & 15 & -8 & 20 & 7 & 7 & -24 & 1 & 16 & 9 & 3 & -24 & -3 \\
\hline $2 a$ & 20 & 25 & 11 & -7 & 19 & 5 & 6 & -10 & 7 & 15 & 10 & 5 & -18 & 6 \\
\hline $2 b$ & 22 & 24 & 18 & -17 & 22 & 8 & 0 & -27 & 3 & 4 & 6 & 5 & -22 & -24 \\
\hline $2 c$ & 28 & 20 & 14 & -5 & 21 & 8 & 17 & -9 & 11 & 14 & 3 & 3 & -20 & 6 \\
\hline $3 a$ & 10 & n.a. & 28 & n.a. & 32 & n.a. & 16 & n.a. & 34 & n.a. & 13 & n.a. & -98 & n.a. \\
\hline $3 b$ & 16 & 9 & 10 & -39 & 36 & 13 & -4 & -36 & 25 & 23 & 2 & -2 & -121 & -93 \\
\hline $3 c$ & 13 & 7 & 14 & -47 & 36 & 17 & 5 & -39 & 12 & 7 & 5 & 4 & -105 & -55 \\
\hline $3 d$ & 10 & 21 & 16 & -45 & 41 & -9 & 9 & -47 & 14 & -2 & 8 & 1 & -97 & -65 \\
\hline
\end{tabular}

${ }^{a}$ All values are given as the percentage of growth inhibition with a $\pm 10 \%$ error. 
(up to $40 \%$ ) for $3 \mathbf{a}-\mathbf{d}$ was observed against the same bacterial strains in absence of iron(III). Presumably competition between the Trojan Horse complex and bacterial siderophore takes place.

Additional RAPTA-like complexes were also tested for antibacterial effects (Table S1). Only one showed significant antibacterial activity against two species ( $S$. aureus and $C$. neoformans), a derivative of RAPTA-C bearing a triphenylphosphine group instead of the PTA moiety. However, this compound was previously found to be quite toxic to HEK293 cells, $^{56}$ probably due to its hydrophobicity, and is not suitable for antibacterial applications. This confirms the potential of $\mathbf{3 b}$ as an antibacterial, since it is structurally similar in the iron(III)-chelated form. Although ligands $2 \mathbf{a}-\mathbf{c}$ showed susceptibility to $C$. neoformans, all ruthenium complexes promote the growth of this fungus. For several Trojan Horse drugs, it was shown that drug release and the use of cleavable linkers, triggered by phosphatase, esterase, ${ }^{40}$ or reductase enzymes, ${ }^{67}$ might be necessary for more potent activity. ${ }^{68}$ The observed relatively low antibacterial activity observed for complexes $3 \mathbf{a}-\mathbf{d}$ could be due to the stability of the linkers.

\section{CONCLUDING REMARKS}

DFO-ligand conjugates $\mathbf{2 a}-\mathbf{c}$ and DFO-containing ruthenium complexes $3 \mathbf{a}-\mathbf{d}$ were synthesized, and their antiproliferative activity was assessed against human cancerous and noncancerous cell lines. Complexes $\mathbf{3 b}$ and $\mathbf{3} \mathbf{c}$ display good cancer cell selectively, despite being less active than cisplatin. The growth inhibitions of several strains of key pathological bacterial strains by ligands $2 \mathbf{a}-\mathbf{c}$, complexes $3 \mathbf{a}-\mathbf{d}$, and some RAPTA-like complexes were also determined. Although only modest growth inhibition was observed, these compounds are an order of magnitude more active than ruthenium compounds modified with antibacterial/antifungal agents. ${ }^{19,21}$ Thus, the modification of ruthenium complexes with DFO, allowing it to be internalized in bacteria, appears to be a more successful approach, with both cytotoxicities and selectivity against cancerous cell lines and similar growth inhibition of different bacterial strains at ten times lower concentrations. Further studies could include the use of other naturally occurring or synthetic siderophores and an evaluation of the use of cleavable linkers.

\section{EXPERIMENTAL SECTION}

Materials. $\mathrm{RuCl}_{3} \cdot x \mathrm{H}_{2} \mathrm{O}$ was purchased from Precious Metals Online. All other chemicals were purchased from Aldrich, Alfa Aesar, Acros, Abcam, and TCI chemicals and used without further purification. $\left[\mathrm{Ru}(p \text {-cymene }) \mathrm{Cl}_{2}\right]_{2}{ }^{69}$ and $[\mathrm{Ru}(\mathrm{PTA})(\mu$-oxalato $)(3-(4-$ methylcyclohexa-1,4-dien-1-yl)propionic acid) $]^{55}$ were prepared following literature procedures. Dichloromethane (DCM) was dried and degassed using a PureSolv solvent purification system (Innovative Technology, Inc.). Thin-layer chromatography was conducted on Merck 60 F254 TLC silica-gel-coated aluminum sheets and verified by a UV lamp at $254 \mathrm{~nm}$ and $\mathrm{KMnO}_{4}$ staining. The compounds were purified via a Varian 971-FP flash chromatography system using prepackaged silica gels columns (Luknova).

Instrumentation and Methods. ${ }^{1} \mathrm{H}(400 \mathrm{MHz}),{ }^{13} \mathrm{C}\left\{{ }^{1} \mathrm{H}\right\}(101$ $\mathrm{MHz})$, and ${ }^{31} \mathrm{P}(162 \mathrm{MHz})$ NMR spectra were recorded on a Bruker Advance II 400 spectrometer at $298 \mathrm{~K}$. Chemical shifts are reported in parts per million and referenced to deuterated solvent residual peaks $\left(\mathrm{CDCl}_{3}:{ }^{1} \mathrm{H}, \delta 7.26 \mathrm{ppm} ;{ }^{13} \mathrm{C}\left\{{ }^{1} \mathrm{H}\right\}, \delta 77.16 \mathrm{ppm}\right.$. DMSO-d $d_{6}:{ }^{1} \mathrm{H}, \delta$ $\left.2.50 \mathrm{ppm} ;{ }^{13} \mathrm{C}\left\{{ }^{1} \mathrm{H}\right\}, \delta 39.52 \mathrm{ppm}\right)$. Coupling constants $(J)$ are reported in hertz $(\mathrm{Hz})$. High-resolution ESI-MS spectra were obtained on Xevo G2-S QTof (Waters) operated in positive-ion mode. Elemental analyses were determined on a Thermo Scientific Flash
2000 organic elemental analyzer. The absorbance of the MTT assay 96-well plates was recorded using a SpectroMax M5e multimode microplate reader (using SoftMax Pro software, version 6.2.2).

Synthesis. Compound 1. To a suspension of 4-(hydroxymethyl)4'-methyl-2,2'-bipyridine ( $0.50 \mathrm{~g}, 2.5 \mathrm{mmol}, 1.0$ equiv) and succinic anhydride $(0.50 \mathrm{~g}, 5.0 \mathrm{mmol}, 2.0$ equiv $)$ in dry DCM $(15 \mathrm{~mL})$ under inert atmosphere was added triethylamine $(1.3 \mathrm{~mL}, 12.5 \mathrm{mmol}, 5.0$ equiv). The reaction mixture was allowed to stir for $72 \mathrm{~h}$, concentrated in vacuo, washed with $\mathrm{Et}_{2} \mathrm{O}(3 \times 15 \mathrm{~mL})$ and hexane $(3 \times 15 \mathrm{~mL})$, and dried. The crude product was then purified by flash column chromatography $(\mathrm{DCM} / \mathrm{MeOH}$ gradient $)$ to yield product $\mathbf{1}(0.63 \mathrm{~g}$, $2.1 \mathrm{mmol}, 84 \%)$ as an off-white solid. ${ }^{1} \mathrm{H}$ NMR $\left(\mathrm{CDCl}_{3}, 400 \mathrm{MHz}\right): \delta$ $8.88\left(\mathrm{br}, 1 \mathrm{H}, \mathrm{CO}_{2} \mathrm{H}\right), 8.65(\mathrm{~d}, J=5.3 \mathrm{~Hz}, 1 \mathrm{H}, \mathrm{ArH}), 8.55(\mathrm{~d}, J=5.1$ $\mathrm{Hz}, 1 \mathrm{H}, \operatorname{Ar} H), 8.28(\mathrm{~s}, 1 \mathrm{H}, \operatorname{Ar} H), 8.19(\mathrm{~s}, 1 \mathrm{H}, \operatorname{ArH}), 7.25(\mathrm{~m}, 1 \mathrm{H}$, $\mathrm{ArH}), 7.22(\mathrm{~m}, 1 \mathrm{H}, \mathrm{ArH}), 5.27\left(\mathrm{~s}, 2 \mathrm{H}, \mathrm{ArCH}_{2} \mathrm{O}\right), 2.79(\mathrm{~m}, 2 \mathrm{H}$, $\left.\mathrm{CH}_{2} \mathrm{CH}_{2} \mathrm{CO}_{2} \mathrm{H}\right), 2.72\left(\mathrm{~m}, 2 \mathrm{H}, \mathrm{CH}_{2} \mathrm{CH}_{2} \mathrm{CO}_{2} \mathrm{H}\right), 2.47(\mathrm{~s}, 3 \mathrm{H}$, $\left.\mathrm{ArCH}_{3}\right) \cdot{ }^{13} \mathrm{C}\left\{{ }^{1} \mathrm{H}\right\}$ NMR $\left(\mathrm{CDCl}_{3}, 101 \mathrm{MHz}\right): \delta 175.1\left(1 \mathrm{C}, \mathrm{CO}_{2} \mathrm{H}\right)$, 172.0 ( $1 \mathrm{C}, \mathrm{CO}_{2} \mathrm{CH}_{2}$ ), 155.8 (1 C, Ar), 155.5 (1 C, Ar), 149.8 (1 C, Ar), 149.5 (1 C, Ar), 148.2 (1 C, Ar), 146.6 (1 C, Ar), 125.3 (1 C, Ar), 123.3 (1 C, Ar), 121.9 (1 C, Ar), 120.1 (1 C, Ar), 64.6 (1 C, $\mathrm{ArCH}_{2}$ ), $30.1\left(1 \mathrm{C}, \mathrm{CH}_{2} \mathrm{CO}_{2} \mathrm{H}\right), 29.9\left(1 \mathrm{C}, \mathrm{CH}_{2} \mathrm{CO}_{2} \mathrm{CH}_{2}\right), 21.4\left(1 \mathrm{C}, \mathrm{ArCH}_{3}\right)$. HRMS (ESI/Q-TOF) $m / z$ : $[\mathrm{M}-\mathrm{H}]^{+}$calcd for $\mathrm{C}_{16} \mathrm{H}_{17} \mathrm{~N}_{2} \mathrm{O}_{4}$ 301.1183, found 301.1185. Anal. Calcd for $\mathrm{C}_{16} \mathrm{H}_{16} \mathrm{~N}_{2} \mathrm{O}_{4}$ : C, 63.99; H, 5.37; N, 9.33. Found: C, 63.74; H, 5.42; N, 9.43.

General Procedure for the Synthesis of DFO Derivatives $2 a-c$. A solution of deferoxamine mesylate (1.0 equiv) and TEA (3.0 equiv) in DMSO was heated at $60^{\circ} \mathrm{C}$ for $30 \mathrm{~min}$. At the same time, a solution of carboxylic acid (1.2 equiv) and CDI (1.2 equiv) in DMF was heated at $60{ }^{\circ} \mathrm{C}$ for $30 \mathrm{~min}$. After $30 \mathrm{~min}$, the solution of activated acid was added dropwise to the other solution, and the reaction mixture was stirred for $1 \mathrm{~h}$ at $60{ }^{\circ} \mathrm{C}$. The reaction was monitored by mass spectrometry and after completion, the solvent was evaporated, and the crude product was purified by flash column chromatography using a $\mathrm{DCM} / \mathrm{MeOH}$ gradient $(0-20 \%$ over $50 \mathrm{~min})$ as eluent.

Compound 2a. According to the general procedure, 2-(pyridin-4$\mathrm{yl}$ )acetic acid (0.05 g, $0.4 \mathrm{mmol}, 1.2$ equiv) and CDI (0.06 g, 0.4 mmol, 1.2 equiv) in DMF $(3 \mathrm{~mL})$ reacted with deferoxamine mesylate $(0.20 \mathrm{~g}, 0.30 \mathrm{mmol}, 1.0$ equiv) and triethylamine $(40 \mu \mathrm{L}, 0.9 \mathrm{mmol}$, 3.0 equiv) in DMSO $(2 \mathrm{~mL})$. The solvent was evaporated, and the crude product was purified by flash column chromatography to afford 2a as a yellow powder $(0.180 \mathrm{~g}, 0.2 \mathrm{mmol}, 88 \%) .{ }^{1} \mathrm{H}$ NMR (DMSO, $400 \mathrm{MHz}): \delta 9.64(\mathrm{~m}, 3 \mathrm{H}, \mathrm{NH} \mathrm{DFO}), 8.61(\mathrm{~d}, J=6.2 \mathrm{~Hz}, 2 \mathrm{H}$, $\mathrm{NArCH}$ pyridyl), $8.20(\mathrm{t}, J=5.7 \mathrm{~Hz}, 1 \mathrm{H}, \mathrm{NOH} \mathrm{DFO}), 7.78(\mathrm{t}, J=5.6$ $\mathrm{Hz}, 2 \mathrm{H}, \mathrm{NOH}$ DFO), 7.53 (d, $J=5.3 \mathrm{~Hz}, 2 \mathrm{H}, \mathrm{ArH}$ pyridyl), 3.59 (s, $\left.2 \mathrm{H}, \mathrm{NHC}(\mathrm{O}) \mathrm{CH}_{2} \mathrm{Ar}\right), 3.45\left(\mathrm{t}, J=7.2 \mathrm{~Hz}, 6 \mathrm{H}, \mathrm{CH}_{2} \mathrm{DFO}\right), 3.01(\mathrm{~m}$, $6 \mathrm{H}, \mathrm{CH}_{2} \mathrm{DFO}$ ), $2.57\left(\mathrm{t}, J=7.3 \mathrm{~Hz}, 4 \mathrm{H}, \mathrm{CH}_{2} \mathrm{DFO}\right.$ ), 2.31 (residual mesylate), $2.26\left(\mathrm{t}, J=7.4 \mathrm{~Hz}, 4 \mathrm{H}, \mathrm{CH}_{2} \mathrm{DFO}\right), 1.96(\mathrm{~s}, 3 \mathrm{H}$, $\left.\mathrm{CH}_{3} \mathrm{C}(\mathrm{O}) \mathrm{DFO}\right), 1.56-1.14\left(\mathrm{~m}, 18 \mathrm{H}, \mathrm{CH}_{2} \mathrm{DFO}\right) .{ }^{13} \mathrm{C}\left\{{ }^{1} \mathrm{H}\right\} \mathrm{NMR}$ (DMSO, $101 \mathrm{MHz}): \delta 172.0$ (2 C, $C$ hydroxamic acid DFO), $171.3(2$ C, $C$ amide DFO), 170.1 (1 C, C hydroxamic acid DFO), 168.1 ( $1 \mathrm{C}$, $\mathrm{C}(\mathrm{O}) \mathrm{N}_{\mathrm{DFO}}$ ), 146.6 (2 C, Ar pyridyl), 125.6 (2 C, Ar pyridyl), 47.1 (DFO), 46.8 (DFO), 41.6 (1 C, $\left.\mathrm{CH}_{2} \mathrm{Ar}\right), 38.6$ (DFO), 38.4 (DFO) 29.9 (DFO), 28.8 (DFO), 28.6 (DFO), 27.6 (DFO), 26.0 (DFO), 23.5 (DFO), 20.4 (DFO). HRMS (ESI/Q-TOF) $\mathrm{m} / z:[\mathrm{M}-\mathrm{H}]^{+}$ calcd for $\mathrm{C}_{32} \mathrm{H}_{54} \mathrm{~N}_{7} \mathrm{O}_{9} 680.3983$, found 680.3978 .

Compound $\mathbf{2 b}$. According to the general procedure, 4(diphenylphosphino)benzoic acid ( $0.05 \mathrm{~g}, 0.2 \mathrm{mmol}, 1.2$ equiv) and CDI (0.03 g, $0.2 \mathrm{mmol}, 1.2$ equiv) in DMF $(2 \mathrm{~mL})$ reacted with deferoxamine mesylate $(0.10 \mathrm{~g}, 0.2 \mathrm{mmol}, 1.0$ equiv) and triethylamine $(20 \mu \mathrm{L}, 0.5 \mathrm{mmol}, 3.0$ equiv) in DMSO $(1 \mathrm{~mL})$. The solvent was evaporated, and the crude product was purified by flash column chromatography to afford product $\mathbf{2 b}$ as an off-white solid $(0.09 \mathrm{~g}, 0.1$ mmol, 74\%). ${ }^{1} \mathrm{H}$ NMR (DMSO, $\left.400 \mathrm{MHz}\right): \delta 9.63(\mathrm{~m}, 3 \mathrm{H}, \mathrm{NH}$ DFO), $8.47(\mathrm{t}, J=5.7 \mathrm{~Hz}, 1 \mathrm{H}, \mathrm{NOH} \mathrm{DFO}), 7.82(\mathrm{~d}, J=7.7 \mathrm{~Hz}, 2 \mathrm{H}$, $\mathrm{C}(\mathrm{O}) \operatorname{Ar} H), 7.80-7.73(\mathrm{~m}, 2 \mathrm{H}, \mathrm{NOH} \mathrm{DFO}), 7.42(\mathrm{~m}, 6 \mathrm{H}, \mathrm{ArH})$, $7.28(\mathrm{~m}, 6 \mathrm{H}, \mathrm{ArH}), 7.20(\mathrm{~s}, 1 \mathrm{H}, \mathrm{ArH}), 3.47\left(\mathrm{q}, J=6.5 \mathrm{~Hz}, 6 \mathrm{H}, \mathrm{CH}_{2}\right.$ DFO), 3.23 (q, $J=6.6 \mathrm{~Hz}, 2 \mathrm{H}, \mathrm{CH}_{2} \mathrm{DFO}$ ), $3.06-2.92\left(\mathrm{~m}, 4 \mathrm{H}, \mathrm{CH}_{2}\right.$ $\mathrm{DFO}), 2.58\left(\mathrm{t}, J=7.4 \mathrm{~Hz}, 4 \mathrm{H}, \mathrm{CH}_{2} \mathrm{DFO}\right), 2.31$ (residual mesylate), $2.27\left(\mathrm{t}, J=7.5 \mathrm{~Hz}, 4 \mathrm{H}, \mathrm{CH}_{2} \mathrm{DFO}\right), 1.97\left(\mathrm{~s}, 3 \mathrm{H}, \mathrm{CH}_{3} \mathrm{C}(\mathrm{O}) \mathrm{DFO}\right)$, $1.53-1.15\left(\mathrm{~m}, 22 \mathrm{H}, \mathrm{CH}_{2} \mathrm{DFO}\right) .{ }^{13} \mathrm{C}\left\{{ }^{1} \mathrm{H}\right\}$ NMR (DMSO, $\left.101 \mathrm{MHz}\right)$ : 
$\delta 172.0$ (2 C, $C$ hydroxamic acid DFO), 171.3 (2 C, $C$ amide DFO), 170.1 ( $1 \mathrm{C}, C$ hydroxamic acid DFO), $165.7\left(1 \mathrm{C}, C(\mathrm{O}) \mathrm{N}_{\mathrm{DFO}}\right), 136.1$ $\left(\mathrm{d},{ }^{1} J=10.9 \mathrm{~Hz}, 1 \mathrm{C}, \mathrm{P}-\mathrm{C}(\mathrm{Ar})\right), 135.0\left(\mathrm{~d},{ }^{1} J=12.4 \mathrm{~Hz}, 2 \mathrm{C}, \mathrm{P}-\mathrm{C}(\mathrm{Ar})\right)$, $133.4\left(\mathrm{~d},{ }^{2} J=19.8 \mathrm{~Hz}, 2 \mathrm{C}, \mathrm{C}(\mathrm{Ar})\right), 132.8\left(\mathrm{~d},{ }^{2} J=19.2 \mathrm{~Hz}, 4 \mathrm{C}\right.$, $C(\mathrm{Ar})$ ), 129.2 (1 C, C(O)CAr), $128.9\left(\mathrm{~d},{ }^{3} \mathrm{~J}=7.0 \mathrm{~Hz}, 2 \mathrm{C}, \mathrm{C}(\mathrm{Ar})\right.$ ), $127.3\left(\mathrm{~d},{ }^{3} \mathrm{~J}=6.6 \mathrm{~Hz}, 4 \mathrm{C}, \mathrm{C}(\mathrm{Ar})\right), 121.0$ (2 C, C(Ar)), 47.6 (DFO), 47.2 (DFO), 38.9 (DFO), 30.4 (DFO), 29.3 (DFO), 28.0 (DFO), 26.5 (DFO), 24.0 (DFO), 20.8 (DFO). ${ }^{31} \mathrm{P}$ NMR (DMSO, 162 $\mathrm{MHz}$ ): $\delta-6.94$. HRMS (ESI/Q-TOF) $\mathrm{m} / z:[\mathrm{M}-\mathrm{Na}]^{+}$calcd for $\mathrm{C}_{44} \mathrm{H}_{61} \mathrm{~N}_{6} \mathrm{O}_{9} \mathrm{PNa} 871.4135$, found 871.4130.

Compound 2 c. According to the general procedure, $4-\left(\left(4^{\prime}-\right.\right.$ methyl[2,2'-bipyridin]-4-yl)methoxy)-4-oxobutanoic acid 1 (0.11 g, 0.4 mmol, 1.2 equiv) and CDI (0.06 g, $0.4 \mathrm{mmol}, 1.2$ equiv) in DMF $(3 \mathrm{~mL})$ reacted with deferoxamine mesylate $(0.20 \mathrm{~g}, 0.3 \mathrm{mmol}, 1.0$ equiv) and triethylamine ( $40 \mu \mathrm{L}, 0.9 \mathrm{mmol}, 3.0$ equiv) in DMSO (2 $\mathrm{mL}$ ). The solvent was evaporated, and the crude product was purified by flash column chromatography to afford $2 \mathrm{c}$ as an off-white solid (0.22 g, $0.26 \mathrm{mmol}, 87 \%) .{ }^{1} \mathrm{H}$ NMR (DMSO, $\left.400 \mathrm{MHz}\right): \delta 9.64$ (m, 3 $\mathrm{H}, \mathrm{NH}$ DFO), 8.65 (d, $J=4.9 \mathrm{~Hz}, 1 \mathrm{H}, \mathrm{ArH}), 8.54(\mathrm{~d}, J=4.8 \mathrm{~Hz}, 1 \mathrm{H}$, $\operatorname{Ar} H$ ), 8.34 (s, $1 \mathrm{H}, \operatorname{Ar} H), 8.24(\mathrm{~s}, 1 \mathrm{H}, \mathrm{ArH}), 8.02$ (residual CDI), $7.85(\mathrm{t}, J=5.4 \mathrm{~Hz}, 1 \mathrm{H}, \mathrm{NOH} \mathrm{DFO}), 7.77(\mathrm{t}, J=4.8 \mathrm{~Hz}, 2 \mathrm{H}, \mathrm{NOH}$ DFO), $7.40(\mathrm{~d}, J=5.0 \mathrm{~Hz}, 1 \mathrm{H}, \mathrm{ArH}), 7.30(\mathrm{~d}, J=5.0 \mathrm{~Hz}, 1 \mathrm{H}, \mathrm{ArH})$, 7.19 (residual CDI), $5.22\left(\mathrm{~s}, 2 \mathrm{H}, \mathrm{CO}_{2} \mathrm{CH}_{2} \mathrm{Ar}\right), 3.45(\mathrm{t}, J=7.0 \mathrm{~Hz}, 6$ $\mathrm{H}, \mathrm{CH}_{2} \mathrm{DFO}$ ), $3.00\left(\mathrm{q}, J=6.6 \mathrm{~Hz}, 6 \mathrm{H}, \mathrm{CH}_{2} \mathrm{DFO}\right), 2.64(\mathrm{t}, J=6.8$ $\left.\mathrm{Hz}, 2 \mathrm{H}, \mathrm{NC}(\mathrm{O}) \mathrm{CH}_{2} \mathrm{CH}_{2} \mathrm{C}(\mathrm{O})\right), 2.57\left(\mathrm{t}, J=7.5 \mathrm{~Hz}, 4 \mathrm{H}, \mathrm{CH}_{2} \mathrm{DFO}\right)$, $2.42\left(\mathrm{~s}, 3 \mathrm{H}, \mathrm{ArCH}_{3}\right), 2.41\left(\mathrm{t}, J=6.9 \mathrm{~Hz}, \mathrm{NC}(\mathrm{O}) \mathrm{CH}_{2} \mathrm{CH}_{2} \mathrm{C}(\mathrm{O})\right), 2.31$ (residual mesylate), $2.26\left(\mathrm{t}, J=7.4 \mathrm{~Hz}, 4 \mathrm{H}, \mathrm{CH}_{2} \mathrm{DFO}\right), 1.96(\mathrm{~s}, 3 \mathrm{H}$, $\mathrm{CH}_{3} \mathrm{C}(\mathrm{O}) \mathrm{DFO}$ ), $1.53-1.18$ (m, $\left.18 \mathrm{H}, \mathrm{CH}_{2} \mathrm{DFO}\right) .{ }^{13} \mathrm{C}\left\{{ }^{1} \mathrm{H}\right\}$ NMR (DMSO, $101 \mathrm{MHz}): \delta 172.2\left(1 \mathrm{C}, \mathrm{C}(\mathrm{O}) \mathrm{N}_{\mathrm{DFO}}\right), 172.0(2 \mathrm{C}, \mathrm{C}$ hydroxamic acid DFO), 171.3 (2 C, C amide DFO), 170.3 (1 C, $\mathrm{CO}_{2} \mathrm{CH}_{2} \mathrm{Ar}$ ), 170.1 (1 C, $\mathrm{C}$ hydroxamic acid DFO), 155.5 (1 C, Ar), 154.8 (1 C, Ar), 149.3 (1 C, Ar), 149.1 (1 C, Ar), 148.0 (1 C, Ar), 146.5 (1 C, Ar), 125.1 ( $1 \mathrm{C}, \mathrm{Ar}), 122.0$ (1 C, Ar), 121.3 (1 C, Ar), 118.5 (1 C, Ar), 63.9 (1 C, $\mathrm{ArCH}_{2}$ ), 47.1 (DFO), 46.8 (DFO), 38.4 (DFO), 29.9 (DFO), 29.8 (1 C, $\left.\mathrm{CH}_{2} \mathrm{CON}_{\mathrm{DFO}}\right), 29.0$ (1 C, $\mathrm{CH}_{2} \mathrm{CO}_{2} \mathrm{CH}_{2}$ ), 28.8 (DFO), 27.6 (DFO), 26.0 (DFO), 23.5 (DFO), 20.7 ( $1 \mathrm{C}, \mathrm{ArCH}_{3}$ ), 20.4 (DFO). HRMS (ESI/Q-TOF) $\mathrm{m} / z$ : [M $\mathrm{H}]^{+}$calcd for $\mathrm{C}_{41} \mathrm{H}_{63} \mathrm{~N}_{8} \mathrm{O}_{11}$ 843.4616, found 843.4611.

General Procedure for the Synthesis of Ruthenium Complexes $3 a-c$. A solution of ligand $2 a-c$ (1.0 equiv) and dichloro( $p$-cymene)ruthenium dimer (1.0 equiv) in methanol was stirred for $1 \mathrm{~h}$. The reaction was monitored by mass spectrometry, and after completion, the crude product was purified.

Compound $3 a$. According to the general procedure, a solution of ligand 2a (0.02 g, $0.03 \mathrm{mmol}, 1.0$ equiv) and dichloro( $p$-cymene) ruthenium dimer $(0.01 \mathrm{~g}, 0.03 \mathrm{mmol}, 1.0$ equiv) in methanol $(10 \mathrm{~mL})$ was stirred for $1 \mathrm{~h}$. After completion, the solvent was evaporated and the crude product washed with DCM $(3 \times 10 \mathrm{~mL})$ and acetone $(3 \times$ $10 \mathrm{~mL})$ to afford pure product $3 \mathrm{a}$ as an orange powder $(0.02 \mathrm{~g}, 0.02$ mmol, 57\%). ${ }^{1} \mathrm{H}$ NMR (DMSO, $\left.400 \mathrm{MHz}\right): \delta 9.69(\mathrm{~m}, 3 \mathrm{H}, \mathrm{NH}$ DFO), 8.47 (d, $J=5.2 \mathrm{~Hz}, 2 \mathrm{H}, \mathrm{NArCH}$ pyridyl), 8.17 (m, $1 \mathrm{H}, \mathrm{NOH}$ DFO), 7.80 (t, $J=5.5 \mathrm{~Hz}, 2 \mathrm{H}, \mathrm{NOH}$ DFO), $7.26(\mathrm{~d}, J=5.2 \mathrm{~Hz}, 2 \mathrm{H}$, ArH pyridyl), 5.82 (d, $J=6.1 \mathrm{~Hz}, 2 \mathrm{H}, \mathrm{ArH}$ p-cymene), 5.78 (d, $J=6.2$ $\mathrm{Hz}, 2 \mathrm{H}, \mathrm{ArH}$ p-cymene), 3.45 (m, $\left.6 \mathrm{H}, \mathrm{CH}_{2} \mathrm{DFO}\right), 3.16$ (d, $J=3.6$ $\left.\mathrm{Hz}, 2 \mathrm{H}, \mathrm{NHC}(\mathrm{O}) \mathrm{CH}_{2} \mathrm{Ar}\right), 3.01\left(\mathrm{~m}, 6 \mathrm{H}, \mathrm{CH}_{2} \mathrm{DFO}\right), 2.83$ (sept, $J=$ $\left.6.9 \mathrm{~Hz}, 1 \mathrm{H}, \mathrm{CH}\left(\mathrm{CH}_{3}\right)_{2}\right), 2.57\left(\mathrm{t}, J=7.3 \mathrm{~Hz}, 4 \mathrm{H}, \mathrm{CH}_{2} \mathrm{DFO}\right), 2.31$ (residual mesylate), $2.27\left(\mathrm{t}, J=7.4 \mathrm{~Hz}, 4 \mathrm{H}, \mathrm{CH}_{2} \mathrm{DFO}\right), 2.09(\mathrm{~s}, 3 \mathrm{H}$, $\left.\mathrm{ArCH}_{3}\right) 1.96\left(\mathrm{~s}, 3 \mathrm{H}, \mathrm{CH}_{3} \mathrm{C}(\mathrm{O}) \mathrm{DFO}\right), 1.56-1.30\left(\mathrm{~m}, 12 \mathrm{H}, \mathrm{CH}_{2}\right.$ DFO), $1.25-1.16\left(\mathrm{~m}, 6 \mathrm{H}, \mathrm{CH}_{2} \mathrm{DFO}\right), 1.19(\mathrm{~d}, J=6.9 \mathrm{~Hz}, 6 \mathrm{H}, i \mathrm{Pr})$. ${ }^{13} \mathrm{C}\left\{{ }^{1} \mathrm{H}\right\}$ NMR (DMSO, $\left.101 \mathrm{MHz}\right): \delta 172.0$ (2 C, $\mathrm{C}$ hydroxamic acid DFO), 171.3 (2 C, $\mathrm{C}$ amide DFO), $170.1\left(1 \mathrm{C}, \mathrm{CH}_{3} \mathrm{C}(\mathrm{O}) \mathrm{N} \mathrm{DFO}\right)$, $168.6\left(1 \mathrm{C}, \mathrm{C}(\mathrm{O}) \mathrm{N}_{\mathrm{DFO}}\right), 149.3\left(1 \mathrm{C}, \mathrm{CH}_{2}-\mathrm{C}(\mathrm{Ar})\right), 145.4(2 \mathrm{C}, \mathrm{Ar}$ pyridyl), 124.5 (2 C, Ar pyridyl), 106.4 (1 C, $\mathrm{ArCCH}_{3}$ arene), 100.1 (1 $\mathrm{C}$, ArCiPr arene), 86.4 (2 C, $\mathrm{CH}$ arene), 85.5 (2C, $\mathrm{CH}$ arene), 48.6 (residual $\mathrm{MeOH}), 47.1$ (DFO), 46.8 (DFO), 41.5 (1 C, $\left.\mathrm{CH}_{2} \mathrm{Ar}\right), 38.6$ (DFO), 38.4 (DFO), 30.2 (1 C, $\left.\mathrm{CH}\left(\mathrm{CH}_{3}\right)_{2}\right) 30.0$ (DFO), 28.8 (DFO), 28.7 (DFO), 27.6 (DFO), 26.0 (DFO), 23.5 (DFO), 21.5 (2C, $i \mathrm{Pr}), 20.4$ (DFO), 17.9 (1 C, $\left.\mathrm{ArCH}_{3}\right)$ ). HRMS (ESI/Q-TOF) $\mathrm{m} /$ $z:[\mathrm{M}-\mathrm{H}]^{+}$calcd for $\mathrm{C}_{42} \mathrm{H}_{66} \mathrm{~N}_{7} \mathrm{O}_{9} \mathrm{Ru}$ 914.3977, found 914.3974.
Compound $\mathbf{3 b}$. According to the general procedure, ligand $\mathbf{2 b}$ $(0.05 \mathrm{~g}, 0.06 \mathrm{mmol}, 1.0$ equiv) and dichloro( $p$ - cymene)ruthenium dimer $(0.02 \mathrm{~g}, 0.06 \mathrm{mmol}, 1.0$ equiv) reacted in methanol $(10 \mathrm{~mL})$ for $1 \mathrm{~h}$. After completion, diethyl ether $(30 \mathrm{~mL})$ was added, and the orange precipitate was washed several times with diethyl ether to afford pure product $3 \mathbf{b}$ as an orange powder $(0.05 \mathrm{~g}, 0.04 \mathrm{mmol}, 83 \%)$. ${ }^{1} \mathrm{H}$ NMR (DMSO, $400 \mathrm{MHz}$ ): $\delta 9.63(\mathrm{~m}, 2 \mathrm{H}, \mathrm{NH}$ DFO), 9.08 (s, 1 $\mathrm{H}, \mathrm{NHC}(\mathrm{O}) \mathrm{Ar}), 7.97$ (m, $4 \mathrm{H}, \operatorname{ArH}), 7.78(\mathrm{~m}, 6 \mathrm{H}, \mathrm{Ar} H), 7.65(\mathrm{~m}, 2$ H, NOH DFO), 7.46 (m, $6 \mathrm{H}, \operatorname{ArH}), 5.36(\mathrm{~d}, J=6.4 \mathrm{~Hz}, 2 \mathrm{H}, \operatorname{ArH} p-$ cymene), 5.29 (d, $J=6.2 \mathrm{~Hz}, 2 \mathrm{H}, \mathrm{ArH}$-cymene), $3.71\left(\mathrm{~m}, 2 \mathrm{H}, \mathrm{CH}_{2}\right.$ DFO), $3.45\left(\mathrm{~m}, 6 \mathrm{H}, \mathrm{CH}_{2} \mathrm{DFO}\right), 3.38\left(\mathrm{t}, J=7.0 \mathrm{~Hz}\right.$, residual $\left.\mathrm{Et}_{2} \mathrm{O}\right)$, $2.98\left(\mathrm{~m}, 5 \mathrm{H}, \mathrm{CH}_{2} \mathrm{DFO}\right.$ and $\left.\mathrm{CH}\left(\mathrm{CH}_{3}\right)_{2}\right), 2.76\left(\mathrm{~m}, 2 \mathrm{H}, \mathrm{CH}_{2} \mathrm{DFO}\right)$, $2.56\left(\mathrm{t}, J=6.8 \mathrm{~Hz}, 4 \mathrm{H}, \mathrm{CH}_{2} \mathrm{DFO}\right), 2.31$ (residual mesylate), $2.27(\mathrm{t}, J$ $\left.=6.5 \mathrm{~Hz}, 4 \mathrm{H}, \mathrm{CH}_{2}\right), 1.96\left(\mathrm{~m}, 3 \mathrm{H}, \mathrm{CH}_{3} \mathrm{C}(\mathrm{O}) \mathrm{DFO}\right), 1.78(\mathrm{~s}, 3 \mathrm{H}$, $\left.\mathrm{ArCH}_{3}\right), 1.60-1.16(\mathrm{~m}, 24 \mathrm{H}), 1.09\left(\mathrm{t}, J=7.0 \mathrm{~Hz}\right.$, residual $\left.\mathrm{Et}_{2} \mathrm{O}\right), 0.95$ (dd, $J=6.9,3.5 \mathrm{~Hz}, 6 \mathrm{H}, i \mathrm{Pr}) .{ }^{13} \mathrm{C}\left\{{ }^{1} \mathrm{H}\right\}$ NMR (DMSO, $\left.101 \mathrm{MHz}\right): \delta$ 172.0 (2 C, $C$ hydroxamic acid DFO), 171.3 (2 C, $C$ amide DFO), 170.6 ( $\left.1 \mathrm{C}, \mathrm{C}(\mathrm{O}) \mathrm{N}_{\mathrm{DFO}}\right), 170.1$ (1 C, C hydroxamic acid DFO), 134.6 (d, ${ }^{1} J=37.0 \mathrm{~Hz}, 2 \mathrm{C}, \mathrm{P}-\mathrm{C}(\mathrm{Ar})$ ), 134.1 (d, J = 9.3 Hz, C(Ar)), 133.6 (d, $\left.{ }^{1} J=29.0 \mathrm{~Hz}, 1 \mathrm{C}, \mathrm{P}-\mathrm{C}(\mathrm{Ar})\right), 130.6(1 \mathrm{C}, \mathrm{C}(\mathrm{O}) \mathrm{C}(\mathrm{Ar})), 128.2(\mathrm{~d}, J=9.8$ $\mathrm{Hz}, \mathrm{C}(\mathrm{Ar})), 128.1$ (d, $J=9.8 \mathrm{~Hz}, \mathrm{CAr}), 119.3$ (2C, C(Ar)), 95.9 (1 C, $\left.\mathrm{ArCCH}_{3}\right), 95.8\left(1 \mathrm{C}, \mathrm{ArCCH}_{2}\right), 89.3(\mathrm{~d}, J=4.0 \mathrm{~Hz}, \mathrm{CH}$ arene $), 87.0$ (d, $J=6.0 \mathrm{~Hz}, \mathrm{CH}$ arene), $86.0(\mathrm{CH}$ arene), 85.5 ( $\mathrm{CH}$ arene), 64.9 (residual $\mathrm{Et}_{2} \mathrm{O}$ ), 47.1 (DFO), 46.8 (DFO), 38.8, 38.4 (DFO), 29.8 (DFO), 28.8 (DFO), 27.6 (DFO), 26.6, 26.0 (DFO), 23.5 (DFO), 22.9, 21.3 (2 C, iPr), 20.4 (DFO). $17.4\left(1 \mathrm{C}, \mathrm{ArCH}_{3}\right), 15.2$ (residual $\mathrm{Et}_{2} \mathrm{O}$ ). ${ }^{31} \mathrm{P}$ NMR (DMSO, $\left.162 \mathrm{MHz}\right): \delta{ }^{31} \mathrm{P}$ NMR $(162 \mathrm{MHz}$, DMSO) $\delta$ 26.0, 25.4, 25.2, 24.0. HRMS (ESI/Q-TOF) $\mathrm{m} / z$ : [M $\mathrm{H}]^{+}$calcd for $\mathrm{C}_{54} \mathrm{H}_{74} \mathrm{~N}_{6} \mathrm{O}_{9} \mathrm{PRu} 1083.4314$, found 1083.4325 .

Compound 3c. According to the general procedure, ligand $2 \mathrm{c}(0.06$ $\mathrm{g}, 0.07 \mathrm{mmol}, 1.0$ equiv) and dichloro $(p$ - cymene)ruthenium dimer $(0.02 \mathrm{~g}, 0.07 \mathrm{mmol}, 1.0$ equiv) reacted in methanol $(10 \mathrm{~mL})$ for $1 \mathrm{~h}$. After completion, diethyl ether $(30 \mathrm{~mL})$ was added, and the orange precipitate was washed several times with diethyl ether to afford pure product $3 \mathrm{c}$ as a yellow powder $(0.06 \mathrm{~g}, 0.04 \mathrm{mmol}, 82 \%) .{ }^{1} \mathrm{H}$ NMR (DMSO, $400 \mathrm{MHz}): \delta 9.71(\mathrm{~m}, 3 \mathrm{H}, \mathrm{NH}), 9.48(\mathrm{~d}, J=5.7 \mathrm{~Hz}, 1 \mathrm{H}$, $\operatorname{ArH}), 9.38(\mathrm{~d}, J=6.0 \mathrm{~Hz}, 1 \mathrm{H}, \mathrm{ArH}), 8.64(\mathrm{~s}, 1 \mathrm{H}, \mathrm{ArH}), 8.51(\mathrm{~m}, 1 \mathrm{H}$, $\mathrm{ArH}), 8.00(\mathrm{t}, J=5.3 \mathrm{~Hz}, 1 \mathrm{H}, \mathrm{NOH}), 7.80(\mathrm{~s}, 2 \mathrm{H}, \mathrm{NOH}), 7.72$ (d, $J$ $=5.5 \mathrm{~Hz}, 1 \mathrm{H}, \operatorname{ArH}), 7.65(\mathrm{t}, J=6.0 \mathrm{~Hz}, 1 \mathrm{H}, \operatorname{ArH}), 6.21(\mathrm{t}, J=5.4 \mathrm{~Hz}$, $2 \mathrm{H}, \operatorname{ArH} p$-cymene), $5.96(\mathrm{t}, J=7.0 \mathrm{~Hz}, 2 \mathrm{H}, \mathrm{ArH}$-cymene), 5.40 (s, $\left.2 \mathrm{H}, \mathrm{CO}_{2} \mathrm{CH}_{2} \mathrm{Ar}\right), 3.45\left(\mathrm{t}, J=7.0 \mathrm{~Hz}, 6 \mathrm{H}, \mathrm{CH}_{2}\right), 3.38(\mathrm{t}, J=7.0 \mathrm{~Hz}$, residual $\left.\mathrm{Et}_{2} \mathrm{O}\right), 2.99\left(\mathrm{q}, \mathrm{J}=6.6 \mathrm{~Hz}, 6 \mathrm{H}, \mathrm{CH}_{2}\right), 2.73-2.66(\mathrm{~m}, 2 \mathrm{H}$, $\mathrm{CH}_{2}$ ), 2.62-2.55 (m, $\left.8 \mathrm{H}, \mathrm{CH}_{2}\right), 2.31$ (residual mesylate), $2.27(\mathrm{t}, \mathrm{J}=$ $\left.7.4 \mathrm{~Hz}, 4 \mathrm{H}, \mathrm{CH}_{2}\right), 2.17\left(\mathrm{~s}, 3 \mathrm{H}, \mathrm{ArCH}_{3}\right), 1.96\left(\mathrm{~s}, 3 \mathrm{H}, \mathrm{CH}_{3} \mathrm{CO}\right)$, $1.53-1.18\left(\mathrm{~m}, 21 \mathrm{H}, \mathrm{CH}_{2}\right.$ and $\left.\mathrm{ArCH}_{3}\right), 1.09(\mathrm{t}, J=7.0 \mathrm{~Hz}$, residual $\left.\mathrm{Et}_{2} \mathrm{O}\right), 0.94(\mathrm{dt}, J=5.0,2.4 \mathrm{~Hz}, 6 \mathrm{H}, i \mathrm{Pr}) .{ }^{13} \mathrm{C}\left\{{ }^{1} \mathrm{H}\right\}$ NMR (DMSO, 101 $\mathrm{MHz}): \delta 172.4\left(1 \mathrm{C}, \mathrm{C}(\mathrm{O}) \mathrm{N}_{\mathrm{DFO}}\right), 172.0(2 \mathrm{C}$, hydroxamic acid $\mathrm{DFO})$, 171.3 (2 C, $\mathrm{C}$ amide DFO), 170.8 ( $1 \mathrm{C}, \mathrm{CO}_{2} \mathrm{CH}_{2} \mathrm{Ar}$ ), 170.1 (1 C, $\mathrm{C}$ hydroxamic acid DFO), 155.4 (1 C, Ar), 155.0 (1 C, Ar), 154.5 (1 C, Ar), 153.8 (1 C, Ar), 152.0 (1 C, Ar), 150.4 (1 C, Ar), 128.4 (1 C, Ar), 124.7 (1 C, Ar), 124.5 (1 C, Ar), 120.4 (1 C, Ar), 103.4 (2 C, Ar pcymene), 86.6 (1 C, Ar p-cymene), 86.4 (1 C, Ar p-cymene), 83.8 (1 $\mathrm{C}$, Ar p-cymene), 83.7 (1 C, Ar p-cymene), 64.9 (residual $\left.\mathrm{Et}_{2} \mathrm{O}\right), 62.9$ (1 C, $\mathrm{ArCH}_{2}$ ), 47.1 (DFO), 46.8 (DFO), 38.4 (DFO), 30.4 (1 C, $\mathrm{CH}_{2} \mathrm{CON}_{\mathrm{DFO}}$ ), 29.9 (DFO), $29.6\left(1 \mathrm{C}, \mathrm{CH}_{2} \mathrm{CO}_{2} \mathrm{CH}_{2}\right), 29.0$ (1 C, $\mathrm{CH}_{2} \mathrm{CO}_{2} \mathrm{CH}_{2}$ ), 28.8 (DFO), 27.6 (DFO), 26.0 (DFO), 23.5 (DFO), 21.7 (2 C, iPr), 20.7 (1 C, $\mathrm{ArCH}_{3}$ bpy), 20.4 (DFO), 18.3 (1 C, $\mathrm{ArCH}_{3}$ arene), 15.2 (residual $\mathrm{Et}_{2} \mathrm{O}$ ). HRMS (ESI/Q-TOF) $\mathrm{m} / z$ : [M] ${ }^{+}$ calcd for $\mathrm{C}_{51} \mathrm{H}_{76} \mathrm{ClN}_{8} \mathrm{O}_{11} \mathrm{Ru} 1113.4376$, found 1113.4366 .

Compound $3 d$. According to a reported procedure, ${ }^{55}[\mathrm{Ru}(\mu$ oxalato)(3-(4-methylcyclohexa-1,4-dien-1-yl)propionic acid) (PTA)] $(0.08 \mathrm{~g}, 0.15 \mathrm{mmol}, 1.0$ equiv) was stirred in DMSO $(2 \mathrm{~mL})$ with TBTU (0.05 g, $0.15 \mathrm{mmol}, 1.0$ equiv) and DIPEA (0.14 mL, 0.75 mmol, 5.0 equiv) for $30 \mathrm{~min}$. Then a solution of deferoxamine mesylate $(0.10 \mathrm{~g}, 0.15 \mathrm{mmol}, 1.0$ equiv) in DMSO $(1 \mathrm{~mL})$ was added dropwise, and the reaction was monitored by MS. After $10 \mathrm{~min}$, the reaction was deemed complete, acetone $(40 \mathrm{~mL})$ was added, and the precipitate was filtered, washed twice with acetone, and dried in vacuo to afford pure product $3 \mathrm{~d}$ as a yellow powder $(0.11 \mathrm{~g}, 0.10 \mathrm{mmol}$, 70\%). ${ }^{1} \mathrm{H}$ NMR ( $\left.\mathrm{CDCl}_{3}, 400 \mathrm{MHz}\right): \delta 9.64$ (m, 3H, NH DFO), 7.86 
$(\mathrm{t}, J=5.5 \mathrm{~Hz}, 1 \mathrm{H}, \mathrm{NOH} \mathrm{DFO}), 7.77(\mathrm{t}, J=5.6 \mathrm{~Hz}, 2 \mathrm{H}, \mathrm{NOH} \mathrm{DFO})$, $5.90(\mathrm{~d}, J=6.0 \mathrm{~Hz}, 2 \mathrm{H}, \mathrm{ArH}$-cymene), $5.83(\mathrm{~d}, J=6.0 \mathrm{~Hz}, 2 \mathrm{H}, \mathrm{ArH}$ p-cymene), 4.45 (m, $\left.6 \mathrm{H}, \mathrm{NCH}_{2} \mathrm{P} \mathrm{PTA}\right), 4.03\left(\mathrm{~s}, 6 \mathrm{H}, \mathrm{NCH}_{2} \mathrm{~N} \mathrm{PTA}\right)$, $3.45\left(\mathrm{t}, J=6.8 \mathrm{~Hz}, 6 \mathrm{H}, \mathrm{CH}_{2} \mathrm{DFO}\right), 3.16\left(\mathrm{~s}, 2 \mathrm{H}, \mathrm{CH}_{2}\right), 2.99(\mathrm{q}, J=$ $\left.6.6 \mathrm{~Hz}, 6 \mathrm{H}, \mathrm{CH}_{2} \mathrm{DFO}\right), 2.57\left(\mathrm{t}, J=7.2 \mathrm{~Hz}, 4 \mathrm{H}, \mathrm{CH}_{2}\right), 2.41(\mathrm{~m}, 4 \mathrm{H}$, $\mathrm{ArCH}_{2} \mathrm{CH}_{2}$ ), $2.26\left(\mathrm{t}, J=7.2 \mathrm{~Hz}, 4 \mathrm{H}, \mathrm{CH}_{2} \mathrm{DFO}\right.$ ), 2.08 (residual acetone), $1.96\left(\mathrm{~s}, 3 \mathrm{H}, \mathrm{CH}_{3} \mathrm{CO} \mathrm{DFO}\right), 1.94\left(\mathrm{~s}, 3 \mathrm{H}, \mathrm{ArCH}_{3}\right), 1.55-$ $1.13\left(\mathrm{~m}, 18 \mathrm{H}, \mathrm{CH}_{2} \mathrm{DFO}\right) .{ }^{13} \mathrm{C}\left\{{ }^{1} \mathrm{H}\right\}$ NMR (DMSO, $\left.101 \mathrm{MHz}\right): \delta$ 172.0 (2 C, hydroxamic acid DFO), 171.3 (2 C, $C$ amide DFO), 170.4 (1 C, $\mathrm{C}(\mathrm{O}) \mathrm{N}_{\mathrm{DFO}}$ ), 170.1 (1 C, C hydroxamic acid DFO), 164.5 (2 C, oxalate), 95.6 (1 C, $\left.\mathrm{ArCCH}_{3}\right), 95.5\left(1 \mathrm{C}, \mathrm{ArCCH}_{2}\right), 88.4$ (d, $2 \mathrm{C}, J=$ $3.3 \mathrm{~Hz}, \mathrm{ArC}), 87.2(\mathrm{~d}, 2 \mathrm{C}, J=3.7 \mathrm{~Hz}, \operatorname{ArC}), 71.8(\mathrm{~d}, J=7.3 \mathrm{~Hz}, 3 \mathrm{C}$, PTA), 49.8 (d, $J=14.2 \mathrm{~Hz}, 3 \mathrm{C}$, PTA), 47.1 (DFO), 46.8 (DFO), 38.4 (DFO), 35.0 ( $\left.1 \mathrm{C}, \mathrm{CH}_{2}\right), 29.9\left(1 \mathrm{C}, \mathrm{CH}_{2}\right), 29.9$ (DFO), 28.8 (DFO), 27.6 (DFO), 26.0 (DFO), 23.5 (DFO), 20.4 (DFO), 17.7 (1 C, $\mathrm{ArCH}_{3}$ ). ${ }^{31} \mathrm{P}$ NMR (DMSO, $162 \mathrm{MHz}$ ): $\delta-33.33$. HRMS (ESI/QTOF) $m / z$ : $[\mathrm{M}-\mathrm{Na}]^{+}$calcd for $\mathrm{C}_{43} \mathrm{H}_{70} \mathrm{~N}_{9} \mathrm{O}_{13} \mathrm{RuNa}$ 1076.3784, found 1076.3815

General Procedure for the Synthesis of Bimetallic Iron and Ruthenium Complexes $\mathrm{Fe}-3 \mathrm{a} / \mathrm{b}$. To a methanolic solution of complex $3 \mathbf{a} / \mathbf{b}$ (1.0 equiv), a methanolic solution of $\mathrm{FeCl}_{3}(74 \mathrm{mM}, 1.0$ equiv) was added. A color change was observed from yellow/orange to red. The solvent was removed by evaporation, and the $\mathrm{Fe}-\mathbf{3 a} / \mathbf{b}$ product was dried in vacuo.

Compound $\mathrm{Fe}-3 \mathrm{a}$. According to the general procedure, complex $\mathbf{3 a}$ ( $0.01 \mathrm{~g}, 0.01 \mathrm{mmol}, 1.0$ equiv) was converted to bimetallic complex Fe-3a (0.01 g, $0.01 \mathrm{mmol}$, quantitative). HRMS (ESI/Q-TOF) $\mathrm{m} / \mathrm{z}$ : $[\mathrm{M}-\mathrm{H}]^{+}$Calcd for $\mathrm{C}_{42} \mathrm{H}_{65} \mathrm{~N}_{7} \mathrm{O}_{9} \mathrm{Cl}_{2} \mathrm{RuFe}$ 1039.2614; Found 1039.2619 .

Compound $\mathbf{F e}-\mathbf{3 b}$. According to the general procedure, complex $\mathbf{3 b}$ ( $0.01 \mathrm{~g}, 0.01 \mathrm{mmol}, 1.0$ equiv) was converted to bimetallic complex Fe-3b (0.01 g, $0.01 \mathrm{mmol}$, quantitative). HRMS (ESI/Q-TOF) $\mathrm{m} / \mathrm{z}$ : $[\mathrm{M}-\mathrm{H}]^{+}$calcd for $\mathrm{C}_{54} \mathrm{H}_{72} \mathrm{~N}_{6} \mathrm{O}_{9} \mathrm{PCl}_{2} \mathrm{RuFeNa}$ 1230.2766, found 1230.2772 .

Discrepancies in the elemental analysis values were found to be higher than the acceptable $0.4 \%$ range and are therefore not reported. Similar observations have been made for other DFO conjugates reported in the literature. ${ }^{70}$ This is due to the high coordination ability of the siderophore that apparently collects metal ions during measurements. NMR and MS data indicate good purity of all compounds.

Stability Studies. The stability of complexes $\mathbf{3 a}-\mathbf{d}$ and their iron(III) derivatives in pseudocell culture conditions was assessed in aqueous $100 \mathrm{mM} \mathrm{NaCl}$ and $5 \%$ DMSO for $72 \mathrm{~h}$ at $298 \mathrm{~K}$ and monitored via ${ }^{1} \mathrm{H}$ and ${ }^{31} \mathrm{P}$ NMR when possible, and ESI-MS(+) otherwise.

Cell Culture and in Vitro Antiproliferative Activity. The human ovarian carcinoma (A2780) cell line was obtained from the European Collection of Cell Cultures. The human embryonic kidney (HEK-293) cell line was obtained from ATCC (Sigma, Buchs, Switzerland). Penicillin streptomycin, RPMI 1640 GlutaMAX (where RPMI = Roswell Park Memorial Institute), and DMEM GlutaMAX media (where DMEM = Dulbecco's modified Eagle medium) were obtained from Life Technologies, and fetal bovine serum (FBS) was obtained from Sigma. The cells were cultured in RPMI 1640 GlutaMAX (A2780) and DMEM GlutaMAX (HEK-293) media containing $10 \%$ heat-inactivated FBS and $1 \%$ penicillin streptomycin at $37{ }^{\circ} \mathrm{C}$ and $\mathrm{CO}_{2}(5 \%)$. The cytotoxicity was determined using the 3(4,5-dimethyl-2-thiazolyl)-2,5-diphenyl- $2 \mathrm{H}$-tetrazolium bromide (MTT) assay. ${ }^{57}$ Cells were seeded in flat-bottomed 96-well plates as a suspension in a prepared medium $(100 \mu \mathrm{L}$ aliquots and approximately 4300 cells/well) and preincubated for $24 \mathrm{~h}$. Stock solutions of compounds were prepared in DMSO and were rapidly diluted in a medium. The solutions were sequentially diluted to give a final DMSO concentration of $0.5 \%$ and a final compound concentration range $(0-200 \mu \mathrm{M})$. Cisplatin was tested as a positive control $(0-10 \mu \mathrm{M})$. RAPTA-C was tested as a negative control (200 $\mu \mathrm{M})$. The compounds were added to the preincubated 96-well plates in $100 \mu \mathrm{L}$ aliquots, and the plates were incubated for $72 \mathrm{~h}$. MTT (20 $\mu \mathrm{L}, 5 \mathrm{mg} / \mathrm{mL}$ in Dulbecco's phosphate buffered saline) was added to the cells, and the plates were incubated for a further $4 \mathrm{~h}$. The culture medium was aspirated, and the purple formazan crystals, formed by the mitochondrial dehydrogenase activity of vital cells, were dissolved in DMSO (100 $\mu \mathrm{L} /$ well). The absorbance of the resulting solutions, directly proportional to the number of surviving cells, was quantified at $590 \mathrm{~nm}$ using a microplate reader. The percentage of surviving cells was calculated from the absorbance of wells corresponding to the untreated control cells. The reported $\mathrm{IC}_{50}$ values (Table 1) are based on the means from three independent experiments, each comprising four tests per concentration level.

Antibacterial Assay. All bacteria were cultured in Cation-adjusted Mueller Hinton broth (CAMHB) at $37{ }^{\circ} \mathrm{C}$ overnight. A sample of each culture was then diluted 40 -fold in fresh broth and incubated at $37{ }^{\circ} \mathrm{C}$ for $1.5-3 \mathrm{~h}$. The resultant mid-log phase cultures were diluted $\left(\mathrm{CFU} / \mathrm{mL}\right.$ measured by $\left.\mathrm{OD}_{600}\right)$ and then added to each well of the compound containing plates, giving a cell density of $5 \times 10^{5} \mathrm{CFU} / \mathrm{mL}$ and a total volume of $50 \mu \mathrm{L}$. All of the plates were covered and incubated at $37{ }^{\circ} \mathrm{C}$ for $18 \mathrm{~h}$ without shaking. Inhibition of bacterial growth was determined measuring absorbance at $600 \mathrm{~nm}\left(\mathrm{OD}_{600}\right)$ using a Tecan M1000 Pro monochromator plate reader. The percentage of growth inhibition was calculated for each well using the negative control (media only) and positive control (bacteria without inhibitors) on the same plate as references. The significance of the inhibition values was determined by modified Z-scores, calculated using the median and MAD of the samples (no controls) on the same plate. Samples with inhibition value above $80 \%$ and Z-Score above 2.5 for either replicate ( $n=2$ on different plates) were classed as actives. Samples with inhibition values between $50-80 \%$ and Z-Score above 2.5 for either replicate ( $n=2$ on different plates) were classed as partial actives. Colistin and vancomycin were used as positive bacterial inhibitor standards for Gram-negative and Gram-positive bacteria, respectively. The antibiotics were provided in four concentrations, with two above and two below its MIC value, and plated into the first 8 wells of column 23 of the 384-well NBS plates. The quality control (QC) of the assays was determined by the antimicrobial controls and the $\mathrm{Z}^{\prime}$-factor (using positive and negative controls). Each plate was deemed to fulfill the quality criteria (pass QC), if the $\mathrm{Z}^{\prime}$-factor was above 0.4 , and the antimicrobial standards showed full range of activity, with full growth inhibition at their highest concentration, and no growth inhibition at their lowest concentration.

Antifungal Assay. Fungi strains were cultured for 3 days on yeast extract-peptone dextrose (YPD) agar at $30^{\circ} \mathrm{C}$. A yeast suspension of $1 \times 10^{6}$ to $5 \times 10^{6} \mathrm{CFU} / \mathrm{mL}$ (as determined by $\mathrm{OD}_{530}$ ) was prepared from five colonies. The suspension was subsequently diluted and added to each well of the compound-containing plates giving a final cell density of fungi suspension of $2.5 \times 10^{3} \mathrm{CFU} / \mathrm{mL}$ and a total volume of $50 \mu \mathrm{L}$. All plates were covered and incubated at $35{ }^{\circ} \mathrm{C}$ for $24 \mathrm{~h}$ without shaking. Growth inhibition of $C$. albicans was determined by measuring absorbance at $530 \mathrm{~nm}\left(\mathrm{OD}_{530}\right)$, while the growth inhibition of $C$. neoformans was determined measuring the difference in absorbance between 600 and $570 \mathrm{~nm}\left(\mathrm{OD}_{600-570}\right)$, after the addition of resazurin $\left(0.001 \%\right.$ final concentration) and incubation at $35{ }^{\circ} \mathrm{C}$ for additional $2 \mathrm{~h}$. The absorbance was measured using a Biotek Synergy HTX plate reader. The percentage of growth inhibition was calculated for each well, using the negative control (media only) and positive control (fungi without inhibitors) on the same plate. The significance of the inhibition values was determined by modified Z-scores, calculated using the median and MAD of the samples (no controls) on the same plate. Samples with inhibition value above $80 \%$ and ZScore above 2.5 for either replicate $(n=2$ on different plates) were classed as actives. Samples with inhibition values between $50-80 \%$ and Z-score above 2.5 for either replicate ( $n=2$ on different plates) were classed as partial actives. Fluconazole was used as a positive fungal inhibitor standard for C. albicans and C. neoformans. 


\section{ASSOCIATED CONTENT}

\section{S Supporting Information}

The Supporting Information is available free of charge on the ACS Publications website at DOI: 10.1021/acs.organomet.7b00885.

NMR stability data of $\mathbf{3 a}-\mathbf{d}$, ESI-MS(+) stability data of Fe-3b, and NMR spectra of all compounds (PDF)

\section{AUTHOR INFORMATION}

\section{Corresponding Author}

*E-mail: paul.dyson@epfl.ch.

\section{ORCID $\odot$}

Paul J. Dyson: 0000-0003-3117-3249

\section{Notes}

The authors declare no competing financial interest.

\section{ACKNOWLEDGMENTS}

Antimicrobial screening was performed by CO-ADD (The Community for Antimicrobial Drug Discovery), funded by the Wellcome Trust (UK) and The University of Queensland (Australia). We thank the Swiss National Science Foundation for financial support and Dr. Euro Solari (EPFL) for performing the elemental analysis.

\section{REFERENCES}

(1) Fleming, A. Clin. Infect. Dis. 1980, 2 (1), 129-139.

(2) Fair, R. J.; Tor, Y. Perspect. Med. Chem. 2014, 6, 25-64.

(3) Capita, R.; Alonso-Calleja, C. Crit. Rev. Food Sci. Nutr. 2013, 53 (1), $11-48$

(4) Maltezou, H. C.; Theodoridou, M.; Daikos, G. L. J. Glob. Antimicrob. Resist. 2017, 10, 75-79.

(5) Holmstrup, P.; Klausen, B. Oral Dis 2017, DOI: 10.1111/ odi.12610.

(6) Huttner, A.; Harbarth, S.; Carlet, J.; Cosgrove, S.; Goossens, H.; Holmes, A.; Jarlier, V.; Voss, A.; Pittet, D. Antimicrob. Resist. Infect. Control 2013, 2 (1), 31.

(7) Muhammad, N.; Guo, Z. Curr. Opin. Chem. Biol. 2014, 19, 144153.

(8) Leijen, S.; Burgers, S. A.; Baas, P.; Pluim, D.; Tibben, M.; van Werkhoven, E.; Alessio, E.; Sava, G.; Beijnen, J. H.; Schellens, J. H. M. Invest. New Drugs 2015, 33 (1), 201-214.

(9) Hartinger, C. G.; Jakupec, M. A.; Zorbas-Seifried, S.; Groessl, M.; Egger, A.; Berger, W.; Zorbas, H.; Dyson, P. J.; Keppler, B. K. Chem. Biodiversity 2008, 5 (10), 2140-2155.

(10) Trondl, R.; Heffeter, P.; Kowol, C. R.; Jakupec, M. A.; Berger, W.; Keppler, B. K. Chem. Sci. 2014, 5 (8), 2925-2932.

(11) Murray, B. S.; Babak, M. V.; Hartinger, C. G.; Dyson, P. J. Coord. Chem. Rev. 2016, 306, 86-114.

(12) Habtemariam, A.; Melchart, M.; Fernández, R.; Parsons, S.; Oswald, I. D. H.; Parkin, A.; Fabbiani, F. P. A.; Davidson, J. E.; Dawson, A.; Aird, R. E.; Jodrell, D. I.; Sadler, P. J. J. Med. Chem. 2006, 49 (23), 6858-6868.

(13) Scolaro, C.; Bergamo, A.; Brescacin, L.; Delfino, R.; Cocchietto, M.; Laurenczy, G.; Geldbach, T. J.; Sava, G.; Dyson, P. J. J. Med. Chem. 2005, 48 (12), 4161-4171.

(14) Weiss, A.; Berndsen, R. H.; Dubois, M.; Müller, C.; Schibli, R.; Griffioen, A. W.; Dyson, P. J.; Nowak-Sliwinska, P. Chem. Sci. 2014, 5 (12), 4742-4748

(15) Nowak-Sliwinska, P.; van Beijnum, J. R.; Casini, A.; Nazarov, A. A.; Wagnières, G.; van den Bergh, H.; Dyson, P. J.; Griffioen, A. W. J. Med. Chem. 2011, 54 (11), 3895-3902.

(16) Allardyce, C. S.; Dyson, P. J.; Ellis, D. J.; Salter, P. A.; Scopelliti, R. J. Organomet. Chem. 2003, 668 (1), 35-42.
(17) Debreczeni, J. É.; Bullock, A. N.; Atilla, G. E.; Williams, D. S.; Bregman, H.; Knapp, S.; Meggers, E. Angew. Chem., Int. Ed. 2006, 45 (10), 1580-1585.

(18) Ang, W. H.; De Luca, A.; Chapuis-Bernasconi, C.; JuilleratJeanneret, L.; Lo Bello, M.; Dyson, P. J. ChemMedChem 2007, 2 (12), $1799-1806$

(19) Kljun, J.; Scott, A. J.; Lanišnik Rižner, T.; Keiser, J.; Turel, I. Organometallics 2014, 33 (7), 1594-1601.

(20) Turel, I.; Kljun, J.; Perdih, F.; Morozova, E.; Bakulev, V.; Kasyanenko, N.; Byl, J. A. W.; Osheroff, N. Inorg. Chem. 2010, 49 (23), $10750-10752$.

(21) Ude, Z.; Romero-Canelón, I.; Twamley, B.; Fitzgerald Hughes, D.; Sadler, P. J.; Marmion, C. J. J. Inorg. Biochem. 2016, 160, 210-217.

(22) de Visser, K. E.; Eichten, A.; Coussens, L. M. Nat. Rev. Cancer 2006, 6 (1), 24-37.

(23) Schaible, U. E.; Kaufmann, S. H. E. Nat. Rev. Microbiol. 2004, 2 (12), 946-953.

(24) Ratledge, C.; Dover, L. G. Annu. Rev. Microbiol. 2000, 54 (1), 881-941.

(25) Winkelmann, G. Biochem. Soc. Trans. 2002, 30 (4), 691-696.

(26) Miethke, M.; Marahiel, M. A. Microbiol. Mol. Biol. Rev. 2007, 71 (3), 413-451.

(27) Braun, V. Front. Biosci., Landmark Ed. 2003, 8, s1409-21.

(28) Hider, R. C.; Kong, X. Nat. Prod. Rep. 2010, 27 (5), 637.

(29) Holden, V. I.; Bachman, M. A. Metallomics 2015, 7 (6), 986995.

(30) Roosenberg, J. M., II; Lin, Y. M.; Lu, Y.; Miller, M. J. Curr. Med. Chem. 2000, 7 (2), 159-197.

(31) Górska, A.; Sloderbach, A.; Marszałl, M. P. Trends Pharmacol. Sci. 2014, 35 (9), 442-449.

(32) Huayhuaz, J. A. A.; Vitorino, H. A.; Campos, O. C.; Serrano, S. H. P.; Kaneko, T. M.; Esposito, B. P. J. Trace Elem. Med. Biol. 2017, 41, $16-22$.

(33) Wencewicz, T. A.; Long, T. E.; Möllmann, U.; Miller, M. J. Bioconjugate Chem. 2013, 24 (3), 473-486.

(34) Paulen, A.; Hoegy, F.; Roche, B.; Schalk, I. J.; Mislin, G. L. A. Bioorg. Med. Chem. Lett. 2017, 27 (21), 4867-4870.

(35) Wencewicz, T. A.; Miller, M. J. Sideromycins as PathogenTargeted Antibiotics. In Topics in Medicinal Chemistry; Springer: Berlin, 2017; pp 1-33.

(36) Faraldo-Gómez, J. D.; Sansom, M. S. P. Nat. Rev. Mol. Cell Biol. 2003, 4 (2), 105-116.

(37) Delcour, A. H. Biochim. Biophys. Acta, Proteins Proteomics 2009, 1794 (5), 808-816.

(38) Braun, V.; Pramanik, A.; Gwinner, T.; Köberle, M.; Bohn, E. BioMetals 2009, 22 (1), 3-13.

(39) Juárez-Hernández, R. E.; Miller, P. A.; Miller, M. J. ACS Med. Chem. Lett. 2012, 3 (10), 799-803.

(40) Ji, C.; Miller, M. J. Bioorg. Med. Chem. 2012, 20 (12), 38283836.

(41) Klahn, P.; Brönstrup, M. Nat. Prod. Rep. 2017, 34 (7), 832-885.

(42) Cohen, A. Semin. Hematol. 1990, 27 (2), 86-90.

(43) Borgias, B.; Hugi, A. D.; Raymond, K. N. Inorg. Chem. 1989, 28 (18), 3538-3545.

(44) Leong, J.; Raymond, K. N. J. Am. Chem. Soc. 1975, 97 (2), $293-$ 296.

(45) Müller, G.; Raymond, K. N. J. Bacteriol. 1984, 160 (1), 304312

(46) Mabeza, G. F.; Loyevsky, M.; Gordeuk, V. R.; Weiss, G. Pharmacol. Ther. 1999, 81 (1), 53-75.

(47) Ferrer, P.; Tripathi, A. K.; Clark, M. A.; Hand, C. C.; Rienhoff, H. Y.; Sullivan, D. J. PLoS One 2012, 7 (5), e37171.

(48) Smith, H. J.; Meremikwu, M. M. In Cochrane Database of Systematic Reviews; Smith, H. J., Ed.; John Wiley \& Sons, Ltd: Chichester, UK, 2003; p CD001474.

(49) Banin, E.; Lozinski, A.; Brady, K. M.; Berenshtein, E.; Butterfield, P. W.; Moshe, M.; Chevion, M.; Greenberg, E. P.; Banin, E. Proc. Natl. Acad. Sci. U. S. A. 2008, 105 (43), 16761-16766. 
(50) Zähner, H.; Diddens, H.; Keller-Schierlein, W.; Nägeli, H. U.

Jpn. J. Antibiot. 1977, 30 (Suppl), 201-206.

(51) Ghosh, A.; Miller, M. J. J. Org. Chem. 1993, 58 (27), 76527659.

(52) Ardon, O.; Weizman, H.; Libman, J.; Shanzer, A.; Chen, Y.; Hadar, Y. Microbiology 1997, 143 (11), 3625-3631.

(53) Ghosh, M.; Lambert, L. J.; Huber, P. W.; Miller, M. J. Bioorg. Med. Chem. Lett. 1995, 5 (20), 2337-2340.

(54) Wilson, J. J.; Lippard, S. J. Inorg. Chim. Acta 2012, 389, 77-84.

(55) Murray, B. S.; Menin, L.; Scopelliti, R.; Dyson, P. J. Chem. Sci. 2014, 5 (6), 2536.

(56) Batchelor, L. K.; Păunescu, E.; Soudani, M.; Scopelliti, R.; Dyson, P. J. Inorg. Chem. 2017, 56 (16), 9617-9633.

(57) Mosmann, T. J. Immunol. Methods 1983, 65 (1-2), 55-63.

(58) Kilpin, K. J.; Clavel, C. M.; Edafe, F.; Dyson, P. J. Organometallics 2012, 31 (20), 7031-7039.

(59) Ang, W. H.; Parker, L. J.; De Luca, A.; Juillerat-Jeanneret, L.; Morton, C. J.; Lo Bello, M.; Parker, M. W.; Dyson, P. J. Angew. Chem., Int. Ed. 2009, 48 (21), 3854-3857.

(60) Murray, B. S.; Crot, S.; Siankevich, S.; Dyson, P. J. Inorg. Chem. 2014, 53 (17), 9315-9321.

(61) Pettinari, R.; Petrini, A.; Marchetti, F.; Pettinari, C.; Riedel, T.; Therrien, B.; Dyson, P. J. Eur. J. Inorg. Chem. 2017, 2017 (12), 18001806.

(62) Biancalana, L.; Batchelor, L. K.; De Palo, A.; Zacchini, S.; Pampaloni, G.; Dyson, P. J.; Marchetti, F. Dalt. Trans. 2017, 46 (36), 12001-12004.

(63) Guerriero, A.; Oberhauser, W.; Riedel, T.; Peruzzini, M.; Dyson, P. J.; Gonsalvi, L. Inorg. Chem. 2017, 56 (10), 5514-5518.

(64) Clavel, C. M.; Păunescu, E.; Nowak-Sliwinska, P.; Griffioen, A. W.; Scopelliti, R.; Dyson, P. J. J. Med. Chem. 2014, 57 (8), 3546-3558. (65) Nowak-Sliwinska, P.; Clavel, C. M.; Păunescu, E.; te Winkel, M. T.; Griffioen, A. W.; Dyson, P. J. Mol. Pharmaceutics 2015, 12 (8), 3089-3096.

(66) Pendleton, J. N.; Gorman, S. P.; Gilmore, B. F. Expert Rev. AntiInfect. Ther. 2013, 11 (3), 297-308.

(67) Ji, C.; Miller, M. J. BioMetals 2015, 28 (3), 541-551.

(68) Wencewicz, T. A.; Möllmann, U.; Long, T. E.; Miller, M. J. BioMetals 2009, 22 (4), 633-648.

(69) Tönnemann, J.; Risse, J.; Grote, Z.; Scopelliti, R.; Severin, K. Eur. J. Inorg. Chem. 2013, 2013 (26), 4558-4562.

(70) Liu, J.; Obando, D.; Schipanski, L. G.; Groebler, L. K.; Witting, P. K.; Kalinowski, D. S.; Richardson, D. R.; Codd, R. J. Med. Chem. 2010, 53 (3), 1370-1382. 